\title{
APPLICATION OF DEA IN BENCHMARKING: A SYSTEMATIC LITERATURE REVIEW FROM 2003-2020
}

\author{
Reza ROSTAMZADEH (D) ${ }^{*}$, Omid AKBARIAN ${ }^{(D)}$, \\ Audrius BANAITIS (D) ${ }^{3}$, Zeynab SOLTANI (D) 4 \\ ${ }^{1}$ Department of Management, Urmia Branch, Islamic Azad University, Urmia, Iran \\ ${ }^{2}$ Department of Management, Tabriz Branch, Islamic Azad University, Tabriz, Iran \\ ${ }^{3}$ Department of Construction Management and Real Estate, \\ Vilnius Gediminas Technical University, 10223, Vilnius, Lithuania \\ ${ }^{4}$ Young Researchers and Elite Club, Tabriz Branch, Islamic Azad University, Tabriz, Iran
}

Received 24 March 2019; accepted 14 June 2020

\begin{abstract}
Benchmarking is an effective method for organizations to increase their productivity, quality of products, reliability of processes or services. The organization may make a comparison between its performance and that of the peers from benchmarking, and recognize their advantages as well as disadvantages. The main objective of the present systematic literature review has been the study of DEA benchmarking process. Therefore, it examined and gave a summary of various DEA models applied worldwide to improve benchmarking. Accordingly, a list of published academic papers that appeared in high-ranking journals between 2003 and February 2020 was collected for a systematic review of the DEA benchmarking application. Consequently, the papers selected have been classified according to year of publication, purpose of research, outcomes and results. This study has identified eight major applications including: transportation, service sector, product planning, maintenance, hotel industry, education, distribution and environmental factors. They take up a total of $82 \%$ of all application-embedded papers. Among all the applications, the highest recent development has been in both the transportation and service sectors. Results showed higher potential of DEA as a suitable evaluation method for the further benchmarking researches, wherein the production feature between outputs and inputs has been practically lacked or very hard to obtain.
\end{abstract}

Keywords: benchmarking, data envelopment analysis (DEA), systematic literature review (SLR).

JEL Classification: C14, C44, C67, L8, L9, M21.

\section{Introduction}

Benchmarking was described as a measure of the quality of the policies, products, services, strategies, etc. of an organization or company, and compared them with the standard measurements or similar measurements of the respective peers. It has been considered as one

*Corresponding author. E-mails: rostamzadeh59@gmail.com; r.rostamzadeh@iaurmia.ac.ir

Copyright (c) 2021 The Author(s). Published by Vilnius Gediminas Technical University

This is an Open Access article distributed under the terms of the Creative Commons Attribution License (http://creativecommons. org/licenses/by/4.0/), which permits unrestricted use, distribution, and reproduction in any medium, provided the original author and source are credited. 
of the common tools that is widely utilized as one of the methods for improving the competitiveness and efficiency of organizations in the business life (Peng Wong \& Yew Wong, 2008). Many papers on benchmarking applications have been published such as management education (Yeravdekar \& Behl, 2017), banking (Radojicic et al., 2018; Sufian, 2011a), airports (Adler et al., 2013), energy systems (Kılkış, 2015; Mardani et al., 2017), transportation (Swanson, 2016), hospitals (Portela et al., 2016), productivity (Chodakowska \& Nazarko, 2017), labour efficiency (Nazarko \& Chodakowska, 2017), supply chain management (Soheilirad et al., 2018; Yazdani et al., 2019), hotels (Chiu \& Lin, 2018), innovative companies (Žižka et al., 2016), asset management (Kaganova \& Telgarsky, 2018) and others, to name only a few. Cook et al. (2004) pointed out that benchmarking and performance evaluation are prominent continual improvement devices, which make organization to evolve continually and ameliorate for surviving and succeeding at aggressive business competition condition (Wu, 2012). Anand and Kodali (2008) proposed that companies have been constantly pressurized for becoming stronger, quicker and more affordable than that of their peers, which benchmarking must be identified as one of the catalysts for change as well as creativity in this regard, and that it can be used as a prime management method by learning from best practices to achieve organizational performance objectives. Barber (2004) stated that the overall aim of benchmarking as the evaluative method for providing continual learning for project organization and project manager is regarded problems, which should discuss more extensively in the discipline of the project management.

Depending on objectives and benchmarking utilization areas, some models may be specified related to it (Quaresma Dias et al., 2009). Deming plan do check act (PDCA) cycle model in researches of (Aires et al., 2014; Silva et al., 2017) the supply-chain operations reference (SCOR) model in researches of (Li et al., 2011; Sellitto et al., 2015) and the data envelopment analysis (DEA) model in researches of (Lim et al., 2011; W. P. Wong \& K. Y. Wong, 2008; Wu et al., 2016). Peng Wong and Yew Wong (2008) claimed that because of (a) robust, (b) standardized, and (c) transparent method of DEA, this can be utilized as one of the benchmarking tools. Second, when multiple performance measures available, it would be one of the important tools for determining comparative efficacy of the peer decision making units (DMUs). Third, this tool assesses efficiency regardless from the definition of the association or interactions between performance indicators before measurement. Forth, it utilizes the definition of an effective frontier as a criterion for performance assessment. In addition, Charnes et al. (1978) introduced DEA as one of the methods to assess efficacy and efficiency of decision making units. DEA was widely known as a modern tool for measuring efficiency (Emrouznejad \& Yang, 2018). However, substantial execution of DEA in performance measurement is one of the reasons for DEA employment as one of the tools for multicriteria decision-making (MCDM). In this type of thinking, decision making units need to be replaced with alternatives, for example, the cost criteria should be a substitute for input, and must to reach its maximum, and the cost criteria should be replaced by the output, which must be the lowest possible value (Makui et al., 2008). One of the most fundamental differences between MCDM and DEA is the impact of human judgment on it. Unlike MCDM, the DEA method attempts to extract the same data and avoids judgment (Belton \& Vickers, 1993; Doyle \& Green, 1993; Papagapiou et al., 1997; Stewart, 1994, 1996). Perhaps it would be better if these two methods work in some cases like each other: the DMUs are carefully 
performed because of the standard criteria and that judgment is not involved. On the other hand, measures taken in the MCDM method can be used to make judgments specifically for limiting weight in DEA (Azadeh et al., 2008). In addition to a comparison of the efficiency throughout the DMUs into an entity, DEA was often employed for comparing efficiency into companies. DEA gains a distinctive merit over other efficiency approaches obtained by benchmarking results. Therefore, both forms of data, output level as well as information on benchmarking, would be indivisible. Therefore, distance of the seen DMU with reference DMU that is used as the benchmarking aim, defines the efficiency (Baek \& Lee, 2009).

The aim of the present article has been to review application of DEA in benchmarking literature. The aim of this article has been the collection of a sample representative of research work on application of DEA in benchmarking processes, emphasizing the utility and applicability of these methods for future study projects Hence, it aimed at the illustration of what areas have been investigated in benchmarking using DEA also which area has the highest growth recently? Based on the studied articles, there is no Systematic Literature Review (SLR) article reviewing the application of DEA in Benchmarking in different fields. On the other hand, there are not many articles which have evaluated the application of DEA in Benchmarking. Therefore, the authors attempted to fill the mentioned gap and systematically review papers of DEA utilization in Benchmarking at a wide scale. In this study, through the analysis of published literature, the research was tested and examined. The purpose of our work is not to review all the common practices in benchmarking among the current method, but focus went for DEA in benchmarking instead. Since the benchmarking plays an important role in a competitive advantage, hence, this paper examines existing methods and focuses on issues that are likely to be faced. Finally, a roadmap is presented to solve current problems. This review is based on DEA-benchmarking. The summary of the contributions are as follows; first, to complete a systematic and comprehensive view of the available DEA presented in the benchmarking to identify the advantages and disadvantages of each area. Second, outlining the key areas wherein further studies may improve the application of DEA methods in the benchmarking.

Therefore, Section 1 presents a discussion of the background of concepts. Then, methodology is described in Section 2. Section 3 reviews the chosen publications. Section 4 discusses results and presents an open issue. Eventually, last section concludes the paper.

\section{Background}

In this section, benchmarking and DEA will be reviewed accordingly.

\subsection{Benchmarking}

History of benchmarking may be originated from the 1800s in the context of textile mills (Bogan \& English, 1994), and it has undergone many developments especially with the emergence of quality management principles. The use of benchmarking as an effective and practical management tools began in the 1980 s by Xerox ${ }^{1}$ Corporation because of losing its market

\footnotetext{
${ }^{1}$ Xerox Corporation is a multinational American company that offers paper solutions and services and information technology products in over 160 countries.
} 
shares and a sense of much pressure from its competitors, especially Japanese companies. Successful lessons learned from Xerox motivated many other organizations to adopt this new approach for raising performance level, production efficiency, and consequently, for the sake to get competitive advantage (Camp, 1989). Benchmarking has spread fast and become one of most used competitive technique (Chen, 2002). It is widely used as a tool to improve performance (Yasin, 2002) eliminate the process of trial and error, enhance efficiency of developing new products (Hong et al., 2014), and improve customer satisfaction (Brah et al., 2000).

In relation to that, benchmarking has numerous definitions in literature. Camp and Camp Robert (1989) presented a commonest definition that described it as "a search to achieve the most acceptable industry exercises that would result in the exceptional results by implementing these best practices". Kumar et al. (2006) emphasized that benchmarking helps to enhance an organization's efficiency by recognizing, understanding and implementing other organizations' good practices. Moreover, it is seeking to find best practice and then trying to apply to achieve the organization's goals. Furthermore, Sarkis (2001) defines benchmarking from a strategic point of view as "a continuous and systematic method for reviewing organization's products, facilities and processes that are known as best practices for organizational development." Although in the related literature, the benchmarking has more than 42 definitions (Heib \& Daneva, 1995), but it can be clearly stated that there is still no proper and comprehensive definition of it (Fernandez et al., 2001). But Wai Peng Wong and Kuan Yew Wong (2008) stated that, according to most authors, the benchmarking as one of the management tools is a systematic process for finding best practices, innovative ideas and performance on the continuous improvement pathway. In our study, the purpose of the improvement is to find a way to perform similar tasks with more efficiency, identifying and implementation of techniques that increase process performance, and determination of output amount (Pickrell et al., 1997). In this regard, Elmuti and Kathawala (1997) argued that benchmarking, as a strategic tool, aims to increase productivity and performance assessment, tools for continual improvements as well as tool for improving performance. In addition, Mollaee and Rahimi (2009) asserted benchmarking aims to achieve continuous improvements through applying five steps:

Step one: Deciding what to benchmark via prioritizing and specifying a specific procedure.

Step two: Analysis of the initial position as well as the objective by determining the measurement devices, which enable to determine the improvement that occurred.

Step three: Choosing an appropriate partner.

Step four: Getting the required insight from the partners.

Step five: Using the lessons learned and activating for improvement.

In line with this vein, benchmarking is an attempt to achieve superior performance by searching for the best practices of others and trying to adopt these practices to suit the conditions of the organization. Asher and Kanji (1996) stated that benchmarking assists organizations to concentrate and be closer to markets and customers. According to (Boxwell Jr, 1994), benchmarking process, in any organization, falls into three approaches namely, training approach, management approach and comprehensive approach. Training approach is often used to enhance competitive awareness in people while management approach is used to fill the 
gaps or handle weaknesses besides improving process in grassroots level. The comprehensive approach of benchmarking is focusing on setting up an inclusive benchmarking process in the organization. Regardless of the approach being used in any organization, there are two points in common. The first point is that organizations are not satisfied of the status quo, and the second point is that organizations are looking forward to enhancing their competitiveness. In other words, benchmarking approaches assist organizations to look outside the box and seek best practices to accomplish goals (Alosani et al., 2016).

\subsection{Data envelopment analysis modeling}

Building on concepts proposed by (Farrell, 1957), Charnes et al. (1978) seminal study "Measuring Efficiency of DMUs" for the first time utilizes the linear programming for estimating an empirical frontier of the production technology. After that, multiple books as well as journal papers have been compiled about the DEA or utilizing the DEA on diverse sets of issues. Assuming that the random error is zero, in the DEA model all the unknown changes are considered as a defect that causes the system to be inefficient. It should be considered that linear programming involves flexible approaches. The DEA technique is a linear and parameter-free programming method. This method is used in cases where the purpose is to compare outputs and inputs of production units or DMUs with each other. This technique is a suitable device to measure and evaluate relative efficiency of manufacturing units or manufacturers. Common and traditional statistical methods serve as one of the crucial tendency approaches and evaluate them by comparing manufacturers' specifications with respect to the average characteristics of a producer. While DEA is an extreme point approach, which compares and evaluates the characteristics of each manufacturer with only the best manufacturers' specifications. In fact, the development of the DEA technique began with the measurement of the productivity in its usual way, the output-to-input ratio. Then, for different inputs, the method of measuring relative efficiency was introduced as the ratio of the weighted output to weighted input. Lai et al. (2011) showed the procedure for DEA model as it is in Figure 1. Comparing with traditional approaches of performance evaluation, DEA has many advantages. The following can be noted as part of its advantages:

- In this technique, weights measurement is done with regard to values of the input and output of each unit that are compared, and there is no need to evaluate the weight of input or output variables or prioritize them.

- Because the DEA technique involves multiple inputs and outputs processing, the relative performance can be measured.

In other hand, the limitations can be summarized as following:

- Exact relative efficiency cannot measure by DEA where return to scale is inconstant.

DEA is recommended to help traditional activities of benchmarking and to provide guidance to management (Donthu et al., 2005). Different experiences indicate that this technique is a powerful tool for evaluating performance and benchmarking to improve and enhance the company's performances. It has been employed in different studies successfully (Martín \& Román, 2006; Min \& Jong Joo, 2006; Seol et al., 2007; Sherman \& Zhu, 2006; Horta et al., 2016). Consequently, since DEA is proposed by Charnes et al. (1978), this method has a widespread utilization for benchmarking studies. DEA has also proven that positively influence determining functions and operating efficiency of different companies (Lai et al., 2011). 


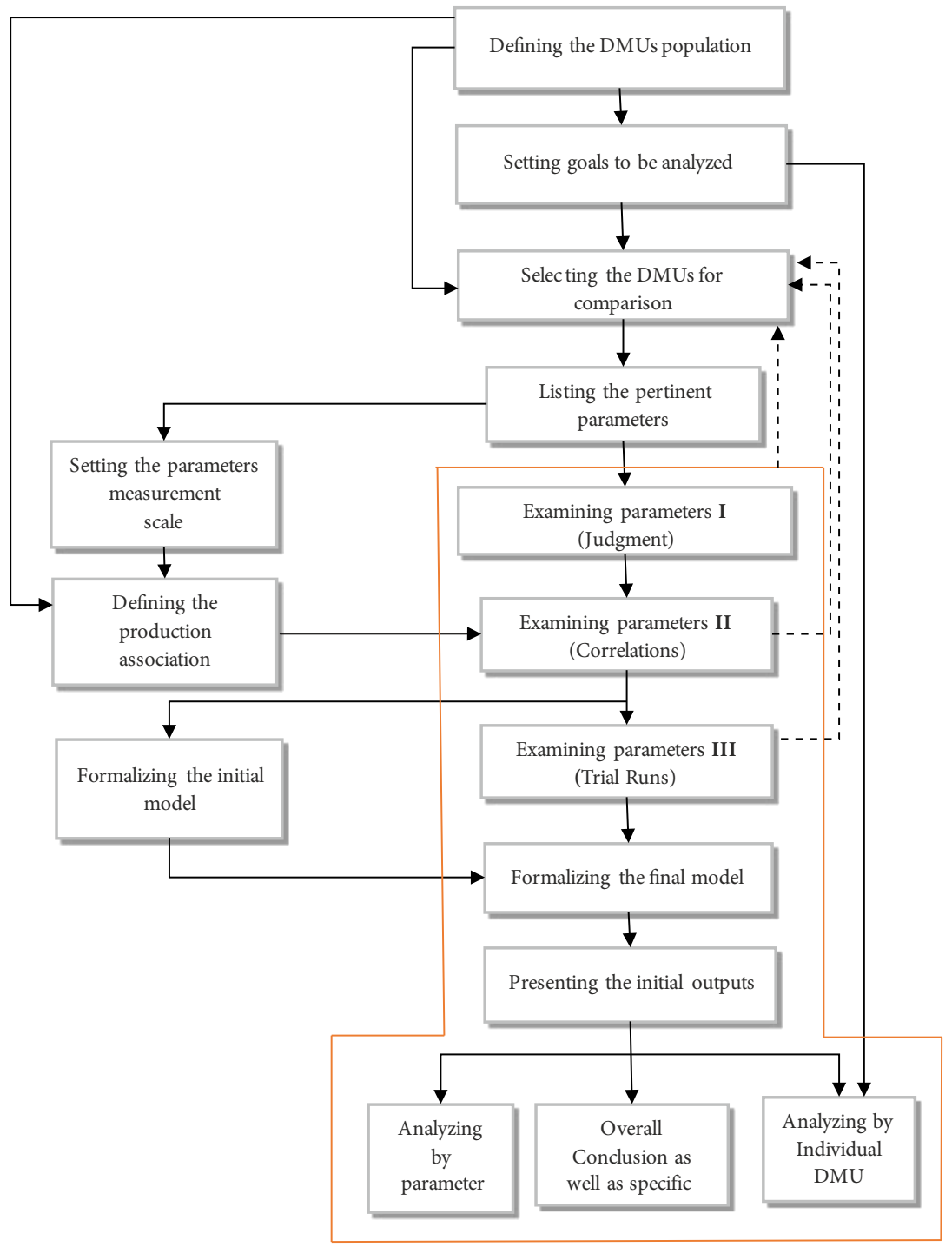

Figure 1. DEA process (Lai et al., 2011)

\section{Systematic review}

Here, an SLR has been utilized for comprehensively studying benchmarking and the application of DEA in benchmarking from 2003. In the next step, the validity of the selected method in this study was evaluated. The search process, including the formalization of the questions, the selection and the classification steps of the article, are described in the following steps. Therefore, we utilized Web of Science (WoS) and Scopus as the 2 major data bases with numerous other online indices like, Science Citation Index Expanded, Social Sciences Citation Index, Arts \& Humanities Citation Index, Conference Proceedings Citation 
Index, to provide the systematic review using DEA in benchmarking. In this stage, search was carried out in these databases to find the articles with regard to diverse keywords like "data envelopment analysis" and "DEA", "benchmarking". Based on our initial searched (topic, keyword, abstracts) in data bases 1377 records have been discovered. After the first phase of our literature search, papers polished with redundant data in order to prevent duplicate records. Upon the completion of the data collection process, the search results have been screened and investigations with an emphasis on the DEA and data envelopment analysis and benchmarking keywords in English, have been maintained. So, 255 articles were deleted. The second selection hallmark relates to the emphasis of abstract for the reduction of the initial sample and uniquely investigates the articles with the abstracts addressing benchmarking concerns. Therefore, we read the chosen abstracts and then two reviewers examined them comprehensively. Hence, among 1122 articles, 1027 papers have been excluded due to irrelevance with the review objectives. The second selection criterion addresses the emphasis of the entire paper. Thus, 2 reviewers read a sample of 95 articles. Then we separated the articles that were based on the DEA approach from the rest of the articles. Notably, 2 researchers screened all articles in the early search outcomes and determined separately if this paper must be embedded in the resulting data-set. Various comments have been elaborated to reach an agreement. However, the resulting data-set contained 51 journal papers reported till the end of April 2020.

Our initial objective is to investigate the applications of benchmarking with DEA techniques. In order to limit our articles collection, the following conditions defined:

1) In order to match the selected articles with the objectives of the study, papers were selected that included their decision-making sciences, computer science, or businessrelated fields. In reviewing articles, research was conducted at data bases like Scopus, Science Direct, Emerald, Springer-Link, and Google Scholar Journals.

2) The keywords for our search were "benchmarking" "data envelopment analysis" "decision making". The literature that had been published in the last 16 years was considered. Therefore, searching led to the identification of 51 investigations that have been regarded to be relevant to be analyzed. Then, number articles were selected and analyzed according to the publication time.

3) In order to be more relevant and more efficient, only articles from international journals were selected. Consequently, the conference papers, unpublished papers, textbooks and notes, and master's and doctoral dissertations have been not studied in our study. The dataset was retrieved presented in the Figure 2.

The classified articles distribution by the benchmarking and DEA approach is described in this section. Furthermore, the articles distribution by publication year is shown in Figure 3. presents variations of total numbers of the investigations on the DEA utilization in benchmarking. The results indicated a constant gradual rate of increased attraction to the DEA as well as benchmarking from 2003. Moreover, number of the publications from 2011 to 2016 growingly enhanced. Such an unexpected enhancement discussed in the newly published researches. Nevertheless, authors presented 21 articles in 2015 till Feb 2020 as the most leading years. As a result, authors are continuously active on the mentioned titles. 


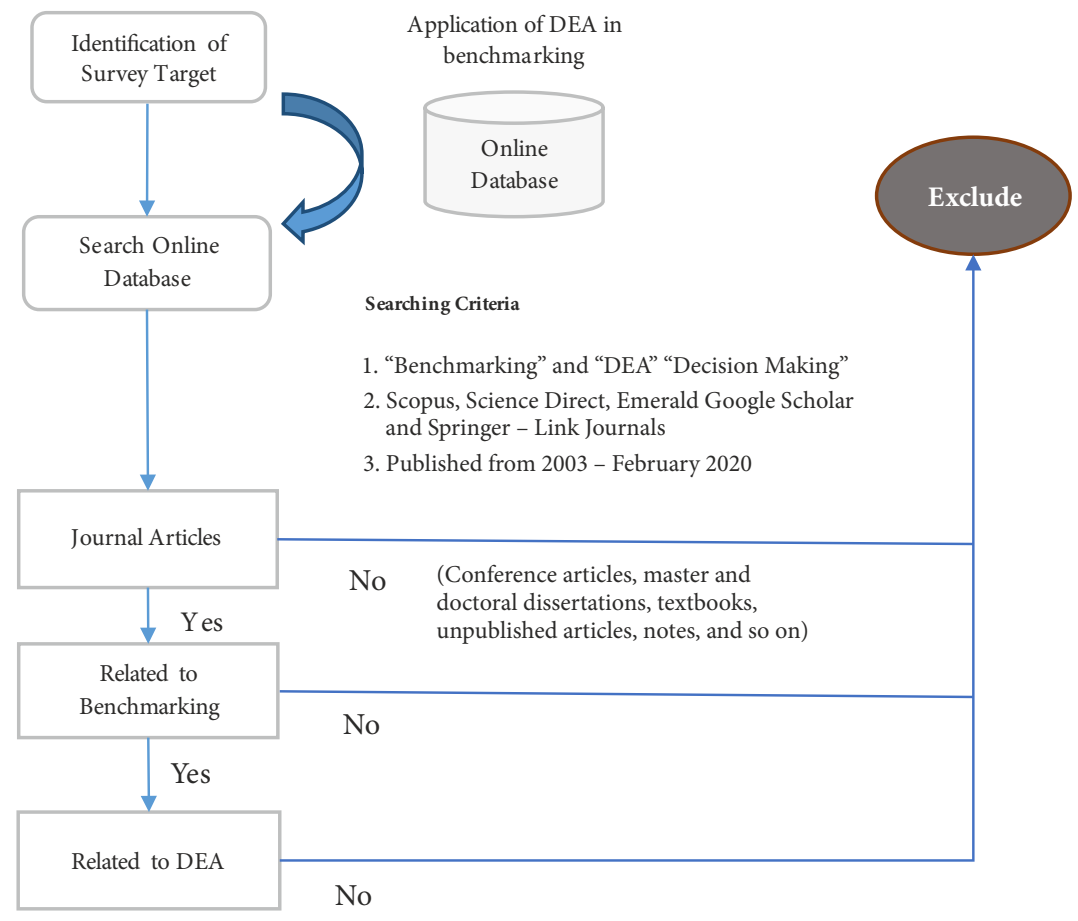

Figure 2. Research methodology of this survey

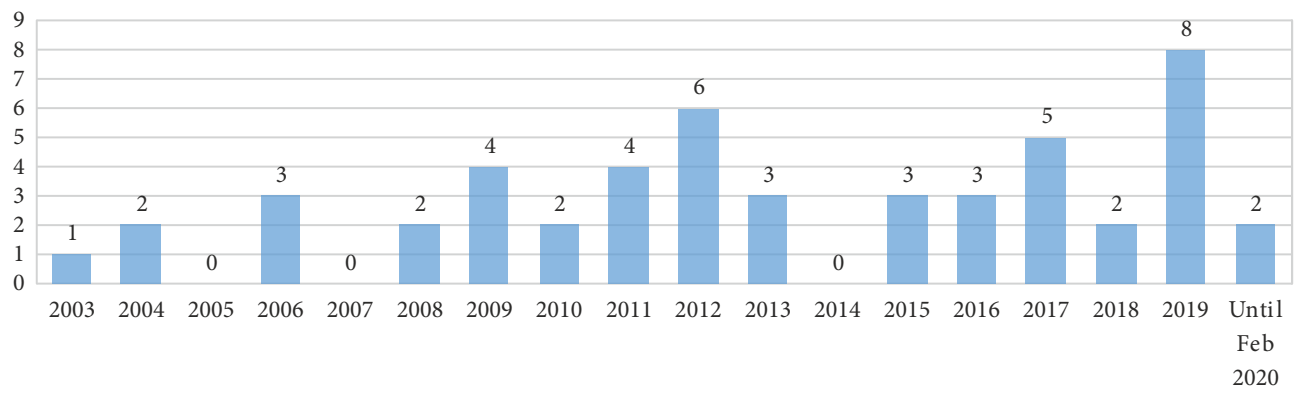

Figure 3. The number of the Benchmarking-DEA articles from 2003 to February 2020

Figure 4 shows different publishers and the articles distribution, where $43.14 \%$ of the total journals article belong to Elsevier. To further investigate, $21.57 \%$ of the literature is related to the Emerald, $9.80 \%$ is related to Taylor and Francis, $9.80 \%$ is associated with Springer, and the remained percent deal, Wiley Online Library, MDPI, World Scientific, International Information Institute, Inderscience, The Institute of Electrical Engineers of Japan and Kluwer Academic Publishers.

To provide a systematic review, the VOS viewer Knowledge Mapping Framework (Van Eck \& Waltman, 2014) was implemented. In this benchmarking exercise, the software helps carry out three important modifications to previously undertaken actions: (1) Evaluation of the 


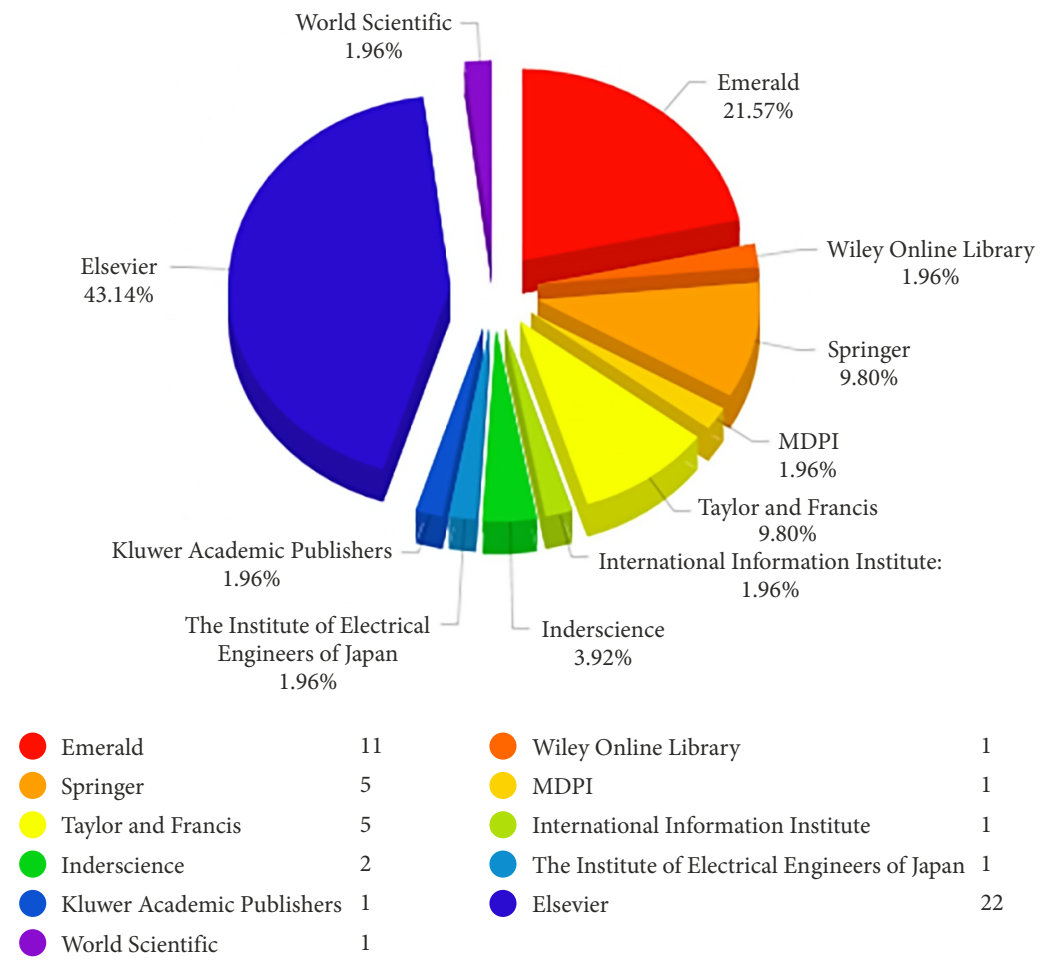

Figure 4. Percent of Benchmarking-DEA articles with regard to various publishers

areas studied become more graphical and the number of analyzed scholarships could increase significantly, (2) systematic identification of content and intellectual structure of the studied areas is possible through the design of a complete set of bibliographic methods, and 3) the content representation of the field's topic could be in detailed by improving the level. By using VOS viewer, the subject can be arranged so that it can be downloaded and the search for the benchmarking field can be dynamically possible, and so readers can explore the intellectual content and structure of it in more detail. All these advantages made VOS viewer to employ widely in order to outline many literatures across the sciences in the past few years and become a popular tool for reviewing and analyzing scholarship (VOS viewer - Publications, 2015).

What topics are being published by Benchmarking and DEA? To find the answer to the question, 4257 distinct terms (title and summary of documents) were examined from 51 documents. The documents examined were printed between 2003 and Feb 2020. The purpose of these actions is to create a network and branches that are relevant to our research. The colors used in the text represent the words in the same subject line. In Figure 5, the color of branches is classified according to their abundance. The red branch is used to display phrases related to "implementation" and "education", blue for the terms related to "criteria", green for terms related to "production" and "branches", yellow for phrases related to "plan" and "performance", sky blue, associated with "customers" and "services", and pink branches associated with "productivity" and "variables”. Definitely, in order to establish rules for firms' competitive objectives, intervention and observational investigations like those released by 
benchmarking and DEA would be needed. The Figure 6 shows the distribution of this study application area.

Figure 6, represents the percent and respective references of all sectors using the DEA in benchmarking. Based on our reviews, transportation sector has maximum rank with $31 \%$. The $2^{\text {nd }}$ rank is associated with other sectors with $19 \%$, industries like service sector with $17 \%$ in the $3^{\text {rd }}$ rank, the fourth rank was associated to education with $9 \%$, environment and product planning with $6 \%$, distribution, hotel industry and maintenance sectors with $4 \%$ are located in the next respectively.

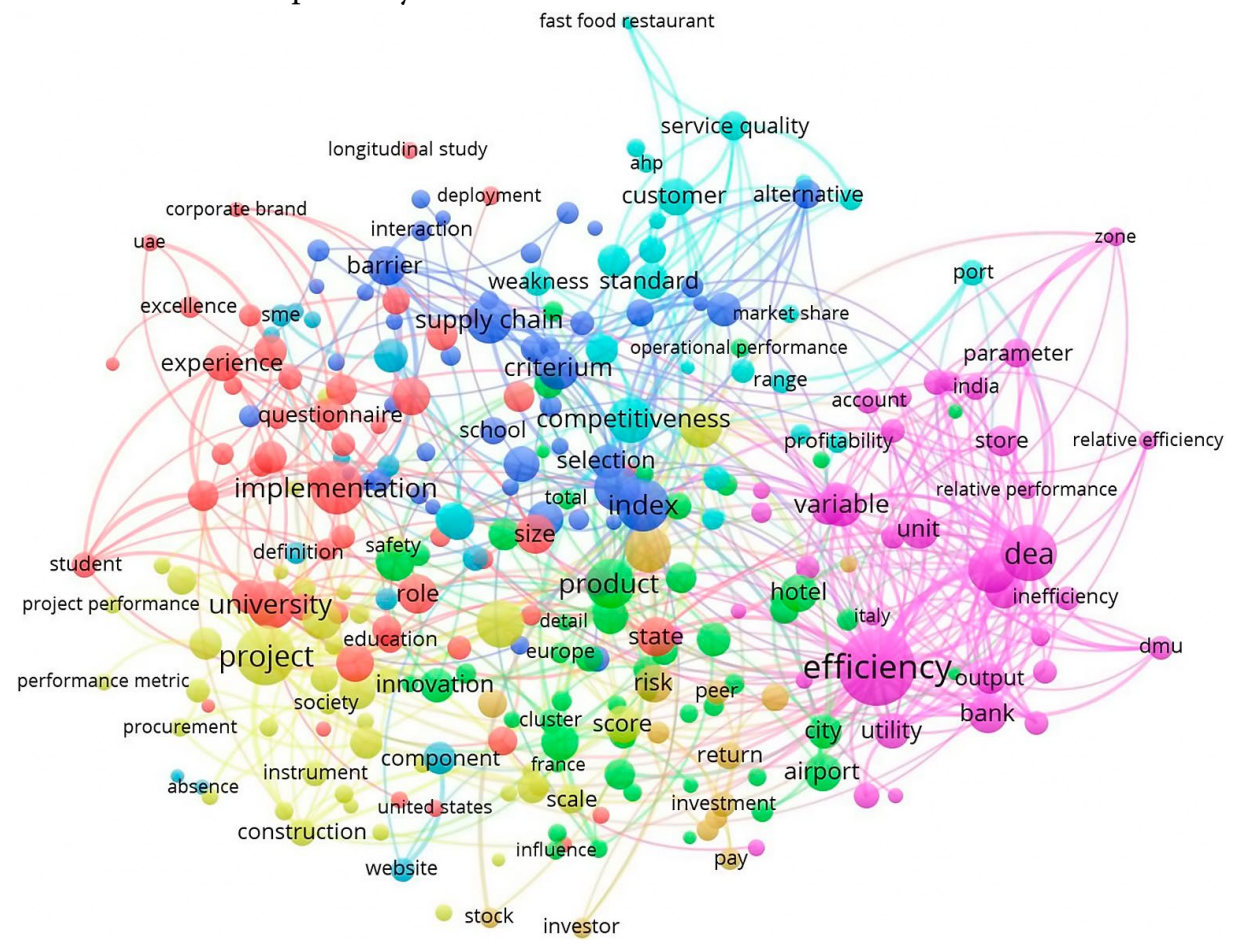

Figure 5. The constructed word co-occurrence network with the words found in the abstracts and topics of the investigations published from 2003-Feb 2020

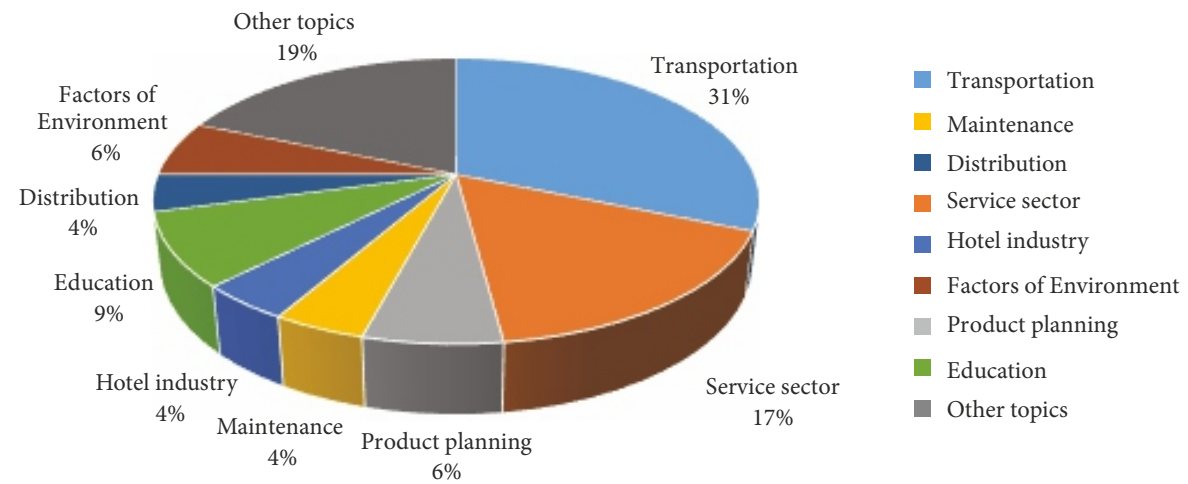

Figure 6. Percent of the prominent DEA application area in benchmarking 


\section{Review of the DEA application area in the benchmarking}

Now, we will present and illustrate the latest utilizations in benchmarking DEA into eight groups. Section 3.1. Transportation, section 3.2. Service sector, section 3.3. Product planning, section 3.4. Maintenance, section 3.5. Hotel industry, section 3.6. Education, section 3.7. Distribution, and section 3.8. Factors of environment and 3.9. Other topics and in each part the related works are discussed.

\subsection{Transportation}

Yoshida and Fujimoto (2004) tried to check the validity of these data by measuring and analyzing the performance of Japanese airports. To do this, the study uses two different methods, namely, DEA as well as endogenous-weight TFP methods. Outputs obtained by the above methods strongly reflect the fact that performance of the regional airports in the mainland Japan is less than other airports. This shows that the airports fabricated in the 1990s have been partially inefficient.

To analyze the relative function of all airports in Spain, the SMOP and DEA ranking methods were used by Martín and Román (2006) this method has also been used to rank all of its efficient and inefficient airports. In previous studies, with regard to relative efficiency, most airports were compared. However, this method does not accurately reflect the overall performance of airports. For this reason, for the full ranking of airports in Spain, six different ratings were used. At the end, they tried to eliminate the deviation between performances gained from the minor productivity indices and performance gained from the proposed ranking methods. To achieve this goal, non-parametric statistical tests were designed to determine correlation between the rankings attained by each method. They proposed the cross-efficiency DEA method as the most acceptable option, which may be utilized in each circumstance for ranking the performance of the airports.

Quaresma Dias et al. (2009) intended for doing benchmarking analyses on the major Iberian Seaports by especial emphasis on the efficiency of their container terminals. They analyzed functions of the Iberian container terminals using the DEA model. To do such an activity, some outputs and inputs associated to this terminal has been gathered and a benchmark analysis has been performed. Variables such as the number of cranes, employees, terminal areas, trailer, yard equipment, and terminal length, the moved TEUs and container movement for one hour via ship were investigated. Hence, it is generally concluded that most of the container terminals have been efficient, although at various levels. Moreover, the Iberian container terminals with the greater performance levels include Alicante, Terminal XXI, Algeciras, and TC Leixões-N. Meanwhile, lowest performance was observed at the Bilbao Container Terminal.

De Koster et al. (2009) contrasted output scores from the benchmarking exercise with the earlier research and addressed reason for conflicting outcomes. This paper uses DEA on primary big container terminal data. The results showed that the greater terminals had higher efficiency and trans-shipment terminals have been considerably more effective in comparison to the terminals for import/export. There are not major difference between ter- 
minals in various areas of the world, between terminals of diverse operators and with distinct stacking material handling systems. Wu et al. (2010) described an approach to evaluate the performance and improve the process of 77 world container ports. They employed a combined multi factor efficiency models, clustering methods as well as aggressive cross-efficiency DEA to assess the container port function and in identification of proper benchmarks to ameliorate the ports with poor performance. In the analysis method used in this study, 4 inputs; that is, Number of Berths, Capacity of Cargo Handling Machines, Storage Capacity, and Terminal Area and one output, namely Container Capacity were selected. Outputs from efficiency values have been examined and a specific arrangement has been made with regard to average cross-efficiency of the ports. In addition, for selecting better targets for poor ports, the cluster analysis has been utilized as one of the benchmarking tools.

Lim et al. (2011) proposed effective methods of benchmarking that DMUs that do not perform well can rely on it and, more practically, achieve their goals. In this method, the DMUs are grouped into layers, which are executed based on their performance. Subsequently, a benchmarking method is created along each layer. The next goal of the benchmarking is based on components such as attractiveness, progression and inaccessibility, selected among the most suitable DMUs in the next layer. By application of this method, it may resolve constraints of typical DEA-based benchmarking. By the use of this method, the performance of 26 container terminals situated at Asia was tested and assessed. Selection of benchmarking objectives was done with regard to a combination of 3 criteria of progress, impossibility, and attractiveness. This led to increased effectiveness, efficiency and ease in benchmarking practices.

Park et al. (2012) investigated improvements in the DEA-based port efficiency as well as selection of the step-wise benchmarking target. Research showed the widespread utilization of DEA to evaluate the port terminals efficiency and derive benchmarking methods. However, these studies have not considered the minimization of resources necessary to select benchmarking target and have not provided any clear information regarding which resources should be preferentially improved to increase efficiency. To address these issues, they propose a DEA based step-wise benchmarking procedure, which can gradationally select benchmarking targets via examining a minimization of the inputs and outputs expansion and can prioritize resources for amelioration of the efficiency. To achieve this goal, they suggested a benchmarking distance minimization model and a sensitivity analysis used DEA method. A benchmarking of 30 major international ports conducted to illustrate the effectiveness of our method. An actual industry application showed this new method may be a more feasible and effective benchmarking one for terminal ports.

Egilmez and McAvoy (2013) conducted relative efficiency and road fatalities reduction efficiency in 50 US states using the DEA-based Malmquist index model. A score in the name of road safety came from an outlet, a deadly fall and five entrances. Based on the results, with an average of $2.1 \%$ reduction in productivity and $1.8 \%$ of technical development, there was some reduction in productivity in minimizing the number of deaths. Thus, although a declining trend has been observed in accident-related deaths, state performance in utilizing social and economic resources is still low for achieving the objective of zeroing mortality. 
Therefore, purpose of this study has been to focus on road safety organizations to explain a more effective policy on improving road safety through increased safety belts and better use of financial resources.

Sharma et al. (2016) examined the performance of rail transport services in delivering rail services and providing a comprehensive notion of service delivery. They defined the quality of the service agents based on limitations such as the availability of data and the rules of the DEA. Hence, quality parameters of the service in their study are being on time, level of general complaints (customer satisfaction) and level of consequential train accidents (safety). The DEA method was utilized as one of the benchmarking tools for evaluation of the performance of 16 Indian Railways (IR). This assessment was performed based on the efficiency and identification of sample areas. The results of this study can act as the performance goals in the reward system, control systems, as well as the performance score-card.

Park and Sung (2016) presented a systematic integrated approach for building a benchmarking network. This method has been considered to be a network structure that includes one of the alternative sequences of the benchmark objectives. In this method, cross-efficiency DEA, the K-means clustering as well as the context dependent DEA are merged with regard to the stability of the pattern of resource improvement and selection based on the IBTs of an inefficient DMU. For example, a 34-port container terminal was tested on a benchmarking network. For inefficient ports such as New York, Valencia, Leam Chabang, and Antwerp, a network of benchmarking was created for the assessment of their UBTs such as Hong Kong, Singapore, Keelung, and Cayenne. However, despite the application of the proposed method, the most suitable DMU in each layer was not found to reach UBT. Also, the minimum stepby-step benchmarking objectives for inefficient DMUs were not determined to reach UBT. However, in organizations with inadequate performance, it is possible to consider numbers of the benchmarking stages as one of the prominent factors in the decision-making procedure to improve efficiency of the stage.

Melo et al. (2018) assessed the measurements of corridors and shipping routes using DEA. In their study, the effectiveness of Brazilian and American transport corridors in the field of soybeans from farm to export terminals was measured and compared with the use of DEA. This paper aimed to find the best route from the smallest production area to the extreme part of the export, in particular using Slack-based measurement (SBM) as well as variables, which are in fact essential pillars (economic, social and environmental) of stability and sustainability. One of the global reports presented in both countries on the transportation of soy is consistent with the outputs from the present research. The most important goal of the research is to examine the criteria for assessing corridors and overall effectiveness. Also, the proposed method in this study can be used in various fields of procurement, such as the generalization of the study to other countries. It can also be used to capitalize on underlying assets.

We reviewed eleven articles reviewed related on application of DEA in benchmarking categorized into transportation industry group. After reviewing the main advantages and disadvantages of each article, it is presented briefly in Table 1. 
Table 1. Summarize of the advantages and disadvantages of transportation articles

\begin{tabular}{|c|c|c|c|c|}
\hline Author & Purpose & Advantage & Disadvantage & $\begin{array}{l}\text { Main suggestion for } \\
\text { future research }\end{array}$ \\
\hline $\begin{array}{l}\text { Yoshida } \\
\text { and } \\
\text { Fujimoto } \\
(2004)\end{array}$ & $\begin{array}{l}\text { Application of the } \\
\text { DEA as well as } \\
\text { EW-TFP for the } \\
\text { measurement of the } \\
\text { Japanese airports' } \\
\text { efficiency }\end{array}$ & $\begin{array}{l}\text { To get "physical" } \\
\text { performance, } \\
\text { focusing in } \\
\text { particular on } \\
\text { the issue of over } \\
\text { investment }\end{array}$ & $\begin{array}{l}\text { Does not contain } \\
\text { financial data } \\
\text { because of } \\
\text { difficulties in data } \\
\text { collection }\end{array}$ & $\begin{array}{l}\text { The transportation } \\
\text { infra-structure } \\
\text { projects like the } \\
\text { airports would be } \\
\text { time-consuming to } \\
\text { generate sufficient } \\
\text { demands for } \\
\text { efficient service. } \\
\text { A potential } \\
\text { extension of the } \\
\text { new researches will } \\
\text { be calculating the } \\
\text { long-term efficacy } \\
\text { by taking this claim } \\
\text { into account }\end{array}$ \\
\hline $\begin{array}{l}\text { Martín and } \\
\text { Román } \\
(2006)\end{array}$ & $\begin{array}{l}\text { To examine the } \\
\text { relative function of } \\
\text { all Spanish airports: } \\
\text { * For ranking } \\
\text { inefficient and } \\
\text { efficient airports in } \\
\text { full; } \\
\text { To compare } 6 \\
\text { distinct strategies } \\
\text { ofbenchmarking with } \\
\text { regard to the DEA } \\
\text { and SMOP making a } \\
\text { comparison between } \\
\text { themSMOP- Cross- } \\
\text { efficiency; } \\
\text { matrix-Super- } \\
\text { efficiency-Virtual } \\
\text { efficiency (champion } \\
\text { performer) }\end{array}$ & $\begin{array}{l}\text { With a specific } \\
\text { weight vector, it } \\
\text { is possible to get } \\
\text { maximum rank } \\
\text { of the efficient } \\
\text { and inefficient } \\
\text { airports that has } \\
\text { been determined } \\
\text { with regard to the } \\
\text { performances of } \\
\text { each sample airport. } \\
\text { Second, ranking } \\
\text { is more reliable } \\
\text { in contrast with } \\
\text { the rest of the } \\
\text { approaches, and } \\
\text { ultimately, ranking } \\
\text { outcomes would be } \\
\text { more accurate than } \\
\text { the outliers remain }\end{array}$ & $\begin{array}{l}\text { This method does } \\
\text { not accurately } \\
\text { reflect the overall } \\
\text { performance of } \\
\text { airports }\end{array}$ & $\begin{array}{l}\text { Perform at airports } \\
\text { in other countries } \\
\text { and do compare }\end{array}$ \\
\hline $\begin{array}{l}\text { Quaresma } \\
\text { Dias et al. } \\
(2009)\end{array}$ & $\begin{array}{l}\text { They utilized DEA } \\
\text { model for assessment } \\
\text { of the function } \\
\text { of main Iberian } \\
\text { container terminals }\end{array}$ & $\begin{array}{l}\text { Data mining as } \\
\text { well as DEA are } \\
\text { used to compare } \\
\text { operational data of } \\
\text { container terminals } \\
\text { at seaports }\end{array}$ & $\begin{array}{l}\text { The decreased } \\
\text { numbers of the } \\
\text { entrance and exits, } \\
\text { validity of data and } \\
\text { extrapolation of the } \\
\text { entrance values. } \\
\text { The data available } \\
\text { on websites of } \\
\text { organizations is not } \\
\text { adequate, is not } \\
\text { trustworthy and is } \\
\text { not presented in a } \\
\text { consistent manner }\end{array}$ & $\begin{array}{l}\text { Through an } \\
\text { investigation, } \\
\text { the approach } \\
\text { may be applied } \\
\text { to the people } \\
\text { responsible for each } \\
\text { terminal service, } \\
\text { with the goal of } \\
\text { validating the data } \\
\text { obtained and even } \\
\text { considering further } \\
\text { years of study }\end{array}$ \\
\hline
\end{tabular}


Continue of Table 1

\begin{tabular}{|c|c|c|c|c|}
\hline Author & Purpose & Advantage & Disadvantage & $\begin{array}{l}\text { Main suggestion for } \\
\text { future research }\end{array}$ \\
\hline $\begin{array}{l}\text { De Koster } \\
\text { et al. } \\
\text { (2009) }\end{array}$ & $\begin{array}{l}\text { Comparison of } \\
\text { the benchmarking } \\
\text { results from the } \\
\text { exercise with those } \\
\text { from previous } \\
\text { research }\end{array}$ & $\begin{array}{l}\text { Description of the } \\
\text { current state of } \\
\text { play by using DEA } \\
\text { methodologies } \\
\text { to evaluate } \\
\text { performances of the } \\
\text { container terminals } \\
\text { at ports }\end{array}$ & $\begin{array}{l}\text { DEA can be } \\
\text { suitable for } \\
\text { benchmarking } \\
\text { of container } \\
\text { terminals, but only } \\
\text { if it is possible } \\
\text { to obtain higher- } \\
\text { quality as well as } \\
\text { further output and } \\
\text { input data }\end{array}$ & $\begin{array}{l}\text { Analysis on terminal } \\
\text { types could be } \\
\text { regulated }\end{array}$ \\
\hline $\begin{array}{l}\text { Jie Wu } \\
\text { et al. } \\
\text { (2010) }\end{array}$ & $\begin{array}{l}\text { Researchers } \\
\text { illustrated the } \\
\text { performance } \\
\text { assessment and } \\
\text { process management } \\
\text { approach of } 77 \text { world } \\
\text { container ports }\end{array}$ & $\begin{array}{l}\text { Cluster analysis } \\
\text { methodology has } \\
\text { been utilized for } \\
\text { selecting the most } \\
\text { suitable objectives } \\
\text { for using as the } \\
\text { benchmarks for } \\
\text { the ports with poor } \\
\text { performance }\end{array}$ & $\begin{array}{l}\text { Although this } \\
\text { research provided } \\
\text { one of the random } \\
\text { samples of the } \\
\text { entire population, } \\
\text { certain extension } \\
\text { of efficiency } \\
\text { and overall } \\
\text { competitiveness of } \\
\text { the industry should } \\
\text { be further assessed }\end{array}$ & $\begin{array}{l}\text { The study as well } \\
\text { as evaluation of } \\
\text { divers' strategies } \\
\text { to clustering, } \\
\text { factor analysis and } \\
\text { multidimensional } \\
\text { scaling may provide } \\
\text { the grounds for } \\
\text { further studies }\end{array}$ \\
\hline $\begin{array}{l}\text { Lim et al. } \\
\text { (2011) }\end{array}$ & $\begin{array}{l}\text { Created a tool for } \\
\text { choosing efficient } \\
\text { benchmarking } \\
\text { paths on which } \\
\text { the inefficient } \\
\text { DMUs would more } \\
\text { effectively attain } \\
\text { their ultimate goals } \\
\text { on the competitive } \\
\text { frontier }\end{array}$ & $\begin{array}{l}\text { The proposed } \\
\text { approach resolves } \\
\text { functional problems } \\
\text { in reference to } \\
\text { several benchmarks, } \\
\text { as is frequently the } \\
\text { case with traditional } \\
\text { benchmarking } \\
\text { based on DEA }\end{array}$ & $\begin{array}{l}\text { The container } \\
\text { terminal } \\
\text { experiment } \\
\text { has been not } \\
\text { a full-scale } \\
\text { implementation; } \\
\text { however, a partial } \\
\text { scale analysis } \\
\text { used only to } \\
\text { demonstrate } \\
\text { this new } \\
\text { approach. Diverse } \\
\text { investigations } \\
\text { required for } \\
\text { a completely } \\
\text { justifiable DEA } \\
\text { utilization have } \\
\text { been facilitated or } \\
\text { neglected }\end{array}$ & $\begin{array}{l}\text { Can create a } \\
0-1 \text { integer } \\
\text { mathematical } \\
\text { programming } \\
\text { model for finding } \\
\text { optimal overall } \\
\text { benchmarking path, } \\
\text { which diminishes } \\
\text { Skpxkp number }\end{array}$ \\
\hline $\begin{array}{l}\text { Park et al. } \\
(2012)\end{array}$ & $\begin{array}{l}\text { Propose a DEA- } \\
\text { based stepwise } \\
\text { benchmarking } \\
\text { procedure, which } \\
\text { may gradationally } \\
\text { choose the } \\
\text { benchmarking } \\
\text { targets }\end{array}$ & $\begin{array}{l}\text { Established stepwise } \\
\text { benchmarking } \\
\text { targets considering } \\
\text { the minimization } \\
\text { of the resource } \\
\text { improvements } \\
\text { for the } 30 \\
\text { terminal ports } \\
\text { and established } \\
\text { resource priorities } \\
\text { for improving the } \\
\text { inefficient ports } \\
\text { efficiency }\end{array}$ & $\begin{array}{l}\text { Their new } \\
\text { methodology } \\
\text { would not consider } \\
\text { numbers of the } \\
\text { benchmarking } \\
\text { stages for an } \\
\text { inefficient port for } \\
\text { reaching the final } \\
\text { benchmarking } \\
\text { target }\end{array}$ & $\begin{array}{l}\text { Controlling } \\
\text { the number of } \\
\text { benchmarking steps } \\
\text { could be a future } \\
\text { research issue }\end{array}$ \\
\hline
\end{tabular}


Continue of Table 1

\begin{tabular}{|c|c|c|c|c|}
\hline Author & Purpose & Advantage & Disadvantage & $\begin{array}{l}\text { Main suggestion for } \\
\text { future research }\end{array}$ \\
\hline $\begin{array}{l}\text { Egilmez } \\
\text { and } \\
\text { McAvoy } \\
(2013)\end{array}$ & $\begin{array}{l}\text { A Malmquist index } \\
\text { model based on } \\
\text { DEA was devised } \\
\text { to evaluate US } \\
\text { productivity and } \\
\text { relative efficiency }\end{array}$ & $\begin{array}{l}\text { Analysis of DEA } \\
\text { findings will be } \\
\text { very useful in } \\
\text { contrasting the } \\
\text { relative quality of } \\
\text { road safety success } \\
\text { with state highway } \\
\text { agencies }\end{array}$ & $\begin{array}{l}\text { Don't find } \\
\text { essential aspects } \\
\text { of fatal crashes } \\
\text { including the } \\
\text { presence of } \\
\text { alcohol, the type of } \\
\text { vehicle (e.g. truck, } \\
\text { passenger car) }\end{array}$ & $\begin{array}{l}\text { More successful } \\
\text { policy making } \\
\text { towards raising the } \\
\text { use of safety belt } \\
\text { and better use of } \\
\text { safeness expenses } \\
\text { for improving the } \\
\text { road conditions } \\
\text { have been extracted } \\
\text { from their research } \\
\text { as the main topics, } \\
\text { which should be } \\
\text { focused on for the } \\
\text { state high-way safety } \\
\text { agencies }\end{array}$ \\
\hline $\begin{array}{l}\text { Sharma } \\
\text { et al. } \\
(2016)\end{array}$ & $\begin{array}{l}\text { Has implemented } \\
\text { a new approach to } \\
\text { benchmarking and } \\
\text { ranking to find the } \\
\text { best sustainable } \\
\text { suppliers }\end{array}$ & $\begin{array}{l}\text { By implementing } \\
\text { these decision } \\
\text { makers, we } \\
\text { recognized the } \\
\text { efficient as well as } \\
\text { inefficient suppliers } \\
\text { and identified the } \\
\text { future suppliers' } \\
\text { inefficiency }\end{array}$ & $\begin{array}{l}\text { There has been } \\
\text { not constantly } \\
\text { feasible that make } \\
\text { a comparison every } \\
\text { field on precisely } \\
\text { the same basis as } \\
\text { the work culture } \\
\text { and difficulties vary } \\
\text { in areas, divisions, } \\
\text { states, and regions } \\
\text { that restrict the } \\
\text { analysis }\end{array}$ & $\begin{array}{l}\text { Similar work can } \\
\text { be replicated with } \\
\text { fuzzy data for other } \\
\text { decision-making } \\
\text { topics, like selection } \\
\text { of product and } \\
\text { technology }\end{array}$ \\
\hline $\begin{array}{l}\text { Park and } \\
\text { Sung } \\
(2016)\end{array}$ & $\begin{array}{l}\text { Proposed a systemic } \\
\text { comprehensive } \\
\text { approach to develop } \\
\text { a benchmarking } \\
\text { network }\end{array}$ & $\begin{array}{l}\text { Have specified } \\
\text { a new protocol } \\
\text { whereby similar } \\
\text { DMUs have been } \\
\text { categorized into } \\
\text { a similar cluster } \\
\text { with regard to the } \\
\text { benchmarking } \\
\text { direction }\end{array}$ & $\begin{array}{l}\text { If there are so } \\
\text { many step-by- } \\
\text { step benchmark } \\
\text { objectives, a } \\
\text { major practical } \\
\text { challenge may } \\
\text { be experienced } \\
\text { for the DMU in } \\
\text { achieving schedule } \\
\text { of benchmarking }\end{array}$ & $\begin{array}{l}\text { The way of picking } \\
\text { the most acceptable } \\
\text { IBT amongst the } \\
\text { number of the } \\
\text { DMUs in all layers } \\
\text { in such a way that } \\
\text { the analyzed DMU } \\
\text { may achieve UBT, } \\
\text { and the way of } \\
\text { application of the } \\
\text { numbers of step-by- } \\
\text { step benchmarking } \\
\text { objectives for more } \\
\text { realistic step-wise } \\
\text { benchmarking } \\
\text { would be challenges, } \\
\text { which should be } \\
\text { considered in } \\
\text { further researches }\end{array}$ \\
\hline
\end{tabular}


End of Table 1

\begin{tabular}{|l|l|l|l|l|}
\hline Author & \multicolumn{1}{|c|}{ Purpose } & \multicolumn{1}{c|}{ Advantage } & Disadvantage & $\begin{array}{l}\text { Main suggestion for } \\
\text { future research }\end{array}$ \\
\hline $\begin{array}{l}\text { Melo et al. } \\
\text { (2018) }\end{array}$ & $\begin{array}{l}\text { To generally evaluate } \\
\text { and measure } \\
\text { efficiency of } \\
\text { transport corridors } \\
\text { for the American } \\
\text { as well as Brazilian } \\
\text { soybeans, from the } \\
\text { farmers to the export } \\
\text { ports, with the use } \\
\text { of DEA }\end{array}$ & $\begin{array}{l}\text { It enhances } \\
\text { the corridor } \\
\text { benchmarking } \\
\text { topic, and usually } \\
\text { emphasizes the } \\
\text { productivity. } \\
\text { It suggests a } \\
\text { framework that can } \\
\text { be implemented in } \\
\text { multiple logistics } \\
\text { contexts, such } \\
\text { as extending the } \\
\text { analysis to include } \\
\text { specific countries }\end{array}$ & $\begin{array}{l}\text { The routes having } \\
\text { more than 3 } \\
\text { modes appear to } \\
\text { have inefficiency } \\
\text { implying a } \\
\text { multimodality limit }\end{array}$ & $\begin{array}{l}\text { It is recommended } \\
\text { to extend and } \\
\text { include variables } \\
\text { such as lead } \\
\text { time, cost of the } \\
\text { maintenance path, } \\
\text { trade disparity, } \\
\text { kind of the cargo } \\
\text { as well as a variable } \\
\text { reflecting social } \\
\text { values like the } \\
\text { operator's life } \\
\text { quality. Further } \\
\text { studies will } \\
\text { concentrate on } \\
\text { directing investment } \\
\text { in the storage field. } \\
\text { Including relation } \\
\text { and carryover } \\
\text { parameters as } \\
\text { well as exploring } \\
\text { possibilities of } \\
\text { other DEA models, } \\
\text { like the structural } \\
\text { window analysis, } \\
\text { the network and } \\
\text { dynamic models, } \\
\text { and other tie } \\
\text { breaking methods } \\
\text { are also suggested }\end{array}$ \\
\hline
\end{tabular}

\subsection{Service sector}

In this regard, Sherman and Zhu (2006) evaluated alternative techniques using quality in the DEA benchmarking. The results indicate that the simple approach to qualitative measures as one of the DEA outputs would not play a role in the diagnose performance. Hence, in the present study, a new DEA-based approach which is quality-balanced (Q-DEA) with a higher sensitivity and quality was presented. The results were implemented in a network of 200 bank branches in the United States. The purpose of this performance measurement was to manage operational costs and service quality. The results of the Q-DEA application, in addition to reducing costs and improving and upgrading operations, was maintaining the quality of service at an appropriate level, which was one of the major goals of the program. Using Q-DEA, new approaches and perspectives have been identified on how for improving operations of the branch with regard to the best practices of high-quality benchmarking (high quality and low cost).

Deville (2009) provided a benchmark analysis of the regional banks and branches from a big French banking group. Therefore, the present analysis aimed at the evaluation of the op- 
erational performance. In fact, "network" of diagnosis was created by performing a diagnosis as "individual" at the branch level. This study mainly aimed to: (i) use inefficient privileges to determine and develop operational performance indicators; and (ii) establish a benchmarking instruction, taking into account the structure of the banking network. This banking group has 1611 branches in 16 regional groups. Therefore, branches work in 6 distinct business environments. Therefore, one method would be needed to (a) collect the inefficiencies of each branch in order to assess regional groups and (b) sum up environmental difference in the assessment guidelines. Results indicate that about $30 \%$ of the branches have efficiency. The main focus and emphasis is on determining the amount of productivity gains at the level of the regional banks, as well as the implementation of the bank's benchmarking.

Baek and Lee (2009) DEA was designed to achieve all goals and the strengths of the respective benchmarking methodology gave DEA a specific merit in comparison to other performance analysis methods. Their research suggested utilization of the Least-Distance Method for obtaining the shortest projection from the measured DMU to the highly efficient output frontier, thereby enabling inefficient DMU for finding the simplest way for improving the performance. The data on 14 general hospitals is used to test the proposed method.

Kumar and Vincent (2011) ranked India's banks, with regard to their performance during the 13 years after the reformation period with a progressive time weighted, using the DEA model. In addition, the relative performance of each bank was evaluated using the DEA method of constant benchmark, compared to the bank that provided the best performance. The results indicate that, when the banks' productivity is assessed on the basis of a common criterion, none of the government banks has superiority over private banks, and vice versa. However, productivity in public banks is more stable than private banks. Results related to Efficiency on the basis of ownership of banks showed, which public sector banks have more stability and order over the years as well as between banks. The results of the comparison of the commonly used ranking method with a progressive approach regarding to the time, have revealed significant disparities in some of the banks.

The purpose of Lai et al. (2011) was to carry out an effective measurement. To this end, the use of a DEA approach, the creation of a rational knowledge-based system (BKBS) to benchmark, as well as the performance review and procedure modification, created an integrated framework. The present study demonstrates how BKBS has been executed at a medical facility. Such a system allows us to identify specific benchmarking partners for assessing the relative performance and bridge the gap between partners in a health metrology industry. Ultimately, a rational KBS provides a quick way for the implementation of the meta-analysis procedures.

Sufian (2011a) utilized DEA to investigate the inefficiency sources in the Korean banking sector. This research concentrated on 3 specific strategies of intermediation, value added, and operational approach in order to distinguish how performance scores varies with the alterations in the input and output.

$\mathrm{Wu}$ (2012) proposed one of the integrated solutions to benchmark with the use of gray entropy, Borda count, as well as DEA. Therefore, the most important component in the process of benchmarking is identifying the best constructor. In order to find the best builder, their suggestion has been the utilization of DEA model with extraordinary efficiency and to apply the gray entropy evaluation method to integrate the ranking list using these two meth- 
ods and Borda counting. The results of the study showed that they were able to discover the best constructor for conscious analysis.

Nigam et al. (2012) investigated mobile service providers in India's telecom system to determine relative efficiency. To evaluate the performance of mobile services, they presented a DEA-based approach. In their study, they examined some of the common concepts between qualitative performance and benchmarking. The results of the study included performance and classification based on public service sensitivity. The comparison of the effectiveness of DEA from the basic model with perturbed models showed that it affected performance. Reporting data for a one-year and three-month period reflects different quality parameters. The DEA method was used to perform benchmarking comparisons of 126 services, which include private and public sector operators (PSUs). Results were compared with performance of efficient and inefficient sectors. With regard to the above findings, inefficient units may implement strategic programs for improving their status.

Karbassi Yazdi and Abdi (2017) reviewed the best banks based on the variables introduced. Banks are initially examined for variables like operating expenses, deposits, employees, net profit, loans, and investment. After that, type of these variables is determined by their input or output. To investigate the efficiency or inefficiency of DMUs using the DEA method, the performance of banks was examined based on these variables. The purpose of this study was finding the most acceptable banks with regard to the previous criteria. Hence, division of criteria into input and output groups was done. The present investigation aimed at implementation of the model with the AP Super Efficiency Model for finding effective units for benchmarking. Because some of the inputs and outputs are more important than other variables for banks, so there should be some changes to the category. According to the outcomes, out of 13 banks (10 public banks and 3 private banks), only five public banks were efficient. In fact, five other public banks were the other three inefficient private banks.

Álvarez-Rodríguez et al. (2019) merged the use of DEA and Life Cycle Assessment (LCA) in the retail sector (grocery stores) for organizational and environmental benchmarking. Researchers confirmed the LCA + DEA approach as one of the valuable tools for evaluating and benchmarking grocery's operational and environmental efficiency as one of the illustrative case studies into the tertiary sector. Hence, it concludes that the LCA + DEA framework is particularly applicable to the service sector. With respect to the particular case study, a fairly suitable environmental and operational output of the grocery collection has been found, each of them included the efficiency scores $>0.6$ and a $1 / 3$ of which are considered to be efficient. This research also demonstrated the viability of utilizing SBM-Max model in the setting LCA + DEA as one of the beneficial methods for the gradual multidimensional benchmarking of related organizations for improving the quality. Such a condition caused complemented benchmarking of less ambitious reduction targets concerning application of the operational inputs in the assessed grocery stores (3 to 13\%). Their outcomes have been additionally enhanced by a super-efficiency analysis, finding two best-performing grocery stores. Overall, the LCA + DEA technique has demonstrated a strong capacity to help decision-makers such as company executives in setting ambitious goals for environmental and operational improvements in the grocery stores in a service industry.

We reviewed 10 articles analyzed and named as service sector. After reviewing the main advantages and disadvantages of each article, it is summarized in Table 2. 
Table 2. Summarizes the advantages and disadvantages of the service articles

\begin{tabular}{|c|c|c|c|c|}
\hline Author & Main Idea & Advantage & Disadvantage & $\begin{array}{l}\text { Main suggestion } \\
\text { for future research }\end{array}$ \\
\hline $\begin{array}{l}\text { Sherman } \\
\text { and Zhu } \\
(2006)\end{array}$ & $\begin{array}{l}\text { Have presented } \\
\text { a novel, more } \\
\text { sensitive, quality } \\
\text { adjusted DEA } \\
\text { (Q-DEA) that } \\
\text { efficiently } \\
\text { addressed the } \\
\text { quality measure in } \\
\text { benchmarking }\end{array}$ & $\begin{array}{l}\text { Recent information } \\
\text { of the manner of } \\
\text { improvement of the } \\
\text { branch operation } \\
\text { with regard to the } \\
\text { most acceptable } \\
\text { practice (higher } \\
\text { quality and lower } \\
\text { costs) }\end{array}$ & $\begin{array}{l}\text { Though } \\
\text { information has } \\
\text { been induced by } \\
\text { Q-DEA analysis, } \\
\text { a motive for } \\
\text { achieving the } \\
\text { cost-saving has } \\
\text { been stronger and } \\
\text { other procedures } \\
\text { may suggest } \\
\text { other methods } \\
\text { for achieving } \\
\text { affordability in the } \\
\text { branch network }\end{array}$ & $\begin{array}{l}\text { It is necessary to perform } \\
\text { additional researches } \\
\text { on the measurement } \\
\text { and incorporation of } \\
\text { the quality into DEA } \\
\text { benchmarking }\end{array}$ \\
\hline $\begin{array}{l}\text { Deville } \\
\text { (2009) }\end{array}$ & $\begin{array}{l}\text { Presenting the } \\
\text { benchmarking } \\
\text { analyses of the } \\
\text { branches as well } \\
\text { as regional banks } \\
\text { of a big French } \\
\text { banking group }\end{array}$ & $\begin{array}{l}\text { Their model } \\
\text { determined one } \\
\text { efficiency frontier } \\
\text { for each kind of } \\
\text { environment }\end{array}$ & $\begin{array}{l}\text { Only done in } \\
\text { branches and } \\
\text { regional banks }\end{array}$ & $\begin{array}{l}\text { One of the } \\
\text { benchmarking analyses } \\
\text { of the branches as well } \\
\text { as the regional banks of } \\
\text { a other country and do } \\
\text { compare }\end{array}$ \\
\hline $\begin{array}{l}\text { Baek } \\
\text { and Lee } \\
(2009)\end{array}$ & $\begin{array}{l}\text { Using the Least- } \\
\text { Distance Measure } \\
\text { for obtaining the } \\
\text { shortest projection } \\
\text { from the assessed } \\
\text { DMU to the } \\
\text { highly efficient } \\
\text { production } \\
\text { frontier }\end{array}$ & $\begin{array}{l}\text { Their new model } \\
\text { produced reasonable } \\
\text { benchmarking } \\
\text { outputs and } \\
\text { provided the } \\
\text { efficiency values, } \\
\text { satisfying general } \\
\text { requirements that } \\
\text { each of the known } \\
\text { efficiency measures } \\
\text { must satisfy }\end{array}$ & $\begin{array}{l}\text { Do not conducted } \\
\text { the meaning of the } \\
\text { relative efficiency in } \\
\text { the traditional DEA } \\
\text { models. } \\
\text { Therefore, ranking } \\
\text { the DMUs with } \\
\text { regard to the } \\
\text { relative efficiency } \\
\text { may be confusing } \\
\text { and unreliable }\end{array}$ & $\begin{array}{l}\text { It is necessary to extend } \\
\text { the Least-Distance } \\
\text { Measure to the non- } \\
\text { convex technology } \\
\text { in the real-world } \\
\text { problems, convex } \\
\text { technology; that is, the } \\
\text { production convexity } \\
\text { possibility set) cannot } \\
\text { be applied. Therefore, } \\
\text { extending to the non- } \\
\text { convexity technology } \\
\text { will ameliorate the } \\
\text { utilization potent of the } \\
\text { Least-Distance Measure }\end{array}$ \\
\hline $\begin{array}{l}\text { Kumar } \\
\text { and } \\
\text { Vincent } \\
(2011)\end{array}$ & $\begin{array}{l}\text { Used diverse } \\
\text { DEA models for } \\
\text { benchmarking the } \\
\text { Indian banks in } \\
\text { the course of the } \\
\text { post-reform era } \\
\text { with regard to the } \\
\text { progressive time } \\
\text { weighted mean } \\
\text { strategy with the } \\
\text { use of the overall } \\
\text { and ownership- } \\
\text { based frontiers }\end{array}$ & $\begin{array}{l}\text { Provided documents } \\
\text { of specific } \\
\text { convergence in the } \\
\text { functions of the } \\
\text { public sector banks } \\
\text { with the respective } \\
\text { counterparts in the } \\
\text { course of the post } \\
\text { reform interval, } \\
\text { which reflected } \\
\text { affirmation of the } \\
\text { impacts of the } \\
\text { reformation process } \\
\text { in the Indian } \\
\text { banking sector }\end{array}$ & $\begin{array}{l}\text { Increasing number } \\
\text { of the production } \\
\text { units decreased the } \\
\text { efficiency scores }\end{array}$ & $\begin{array}{l}\text { Comparing the } \\
\text { efficiency levels among } \\
\text { the industries required } \\
\text { adjustments for the size } \\
\text { of the samples }\end{array}$ \\
\hline
\end{tabular}


Continue of Table 2

\begin{tabular}{|c|c|c|c|c|}
\hline Author & Main Idea & Advantage & Disadvantage & $\begin{array}{l}\text { Main suggestion } \\
\text { for future research }\end{array}$ \\
\hline $\begin{array}{l}\text { Lai et al. } \\
\text { (2011) }\end{array}$ & $\begin{array}{l}\text { Devising a } \\
\text { knowledge- } \\
\text { based system to } \\
\text { benchmark with } \\
\text { regard to the DEA } \\
\text { strategy }\end{array}$ & $\begin{array}{l}\text { It has been } \\
\text { found that the } \\
\text { medical center } \\
\text { administrators } \\
\text { may utilize this } \\
\text { analysis for helping } \\
\text { them determine } \\
\text { and handle the } \\
\text { benchmarking } \\
\text { procedure while } \\
\text { adopting the BKBS }\end{array}$ & $\begin{array}{l}\text { Research in the } \\
\text { medical industry } \\
\text { has been limited }\end{array}$ & $\begin{array}{l}\text { Benchmarking } \\
\text { knowledge-based } \\
\text { system should integrate } \\
\text { RBR, the case based } \\
\text { and model-based } \\
\text { reasoning to benchmark } \\
\text { the implementation, } \\
\text { evaluation of the } \\
\text { performance and } \\
\text { improvements in the } \\
\text { process. } \\
\text { Hence, it is necessary for } \\
\text { the BKBS to integrate the } \\
\text { mentioned management } \\
\text { devices to benchmark } \\
\text { the process }\end{array}$ \\
\hline $\begin{array}{l}\text { Sufian } \\
\text { (2011a) }\end{array}$ & $\begin{array}{l}\text { Essentially } \\
\text { examined } \\
\text { the source of } \\
\text { inefficiency in the } \\
\text { Korean banking } \\
\text { sector }\end{array}$ & $\begin{array}{l}\text { Focused on } 3 \\
\text { distinct strategies } \\
\text { of intermediation, } \\
\text { value added } \\
\text { approach, as well } \\
\text { as the operating } \\
\text { approach for } \\
\text { differentiating how } \\
\text { efficiency scores } \\
\text { change with the } \\
\text { variations in the } \\
\text { outputs and inputs }\end{array}$ & $\begin{array}{l}\text { Considering } \\
\text { changes in } \\
\text { productivity over } \\
\text { time can affect the } \\
\text { outcome of this } \\
\text { research }\end{array}$ & $\begin{array}{l}\text { Examining the } \\
\text { productivity experiences } \\
\text { some modifications } \\
\text { during time. Due to } \\
\text { the technical changes, } \\
\text { technological advances } \\
\text { or regression with the } \\
\text { use of the Malmquist } \\
\text { productivity index may } \\
\text { be one of the other } \\
\text { extensions to the article }\end{array}$ \\
\hline $\begin{array}{l}\text { Wu } \\
(2012)\end{array}$ & $\begin{array}{l}\text { Their study } \\
\text { proposed the } \\
\text { use of the super } \\
\text { efficiency DEA } \\
\text { model as well } \\
\text { as gray entropy } \\
\text { (GE) scoring } \\
\text { for conducting } \\
\text { the pertinent } \\
\text { efficiency } \\
\text { assessment } \\
\text { and ranking, } \\
\text { and utilizing } \\
\text { Borda count for } \\
\text { incorporating the } \\
\text { ranked lists }\end{array}$ & $\begin{array}{l}\text { Undertook the task } \\
\text { of demonstration } \\
\text { of the utility } \\
\text { of a suggested } \\
\text { integrated solution } \\
\text { to benchmark in } \\
\text { order to search the } \\
\text { most acceptable } \\
\text { performer and } \\
\text { involved in } \\
\text { extending the } \\
\text { feasible uses via } \\
\text { incorporation of the } \\
\text { GE, Borda count, } \\
\text { and DEA }\end{array}$ & $\begin{array}{l}\text { The limitation } \\
\text { that though } \\
\text { Borda count is } \\
\text { greatly easy and } \\
\text { understandable, it } \\
\text { would not take into } \\
\text { account priority } \\
\text { for all individual } \\
\text { ranked lists }\end{array}$ & $\begin{array}{l}\text { As the ranked lists } \\
\text { obtained from the } \\
\text { mentioned } 2 \text { methods } \\
\text { have been not generally } \\
\text { equivalent, their } \\
\text { recommendation was the } \\
\text { use of Borda count for } \\
\text { coalescing the ranked } \\
\text { lists into a single ranked } \\
\text { list }\end{array}$ \\
\hline
\end{tabular}


End of Table 2

\begin{tabular}{|c|c|c|c|c|}
\hline Author & Main Idea & Advantage & Disadvantage & $\begin{array}{l}\text { Main suggestion } \\
\text { for future research }\end{array}$ \\
\hline $\begin{array}{l}\text { Nigam } \\
\text { et al. } \\
\text { (2012) }\end{array}$ & $\begin{array}{l}\text { The researchers } \\
\text { proposed a } \\
\text { method to } \\
\text { benchmark the } \\
\text { performance } \\
\text { of the mobile } \\
\text { telecom utility on } \\
\text { the basis of the } \\
\text { DEA }\end{array}$ & $\begin{array}{l}\text { Identified various } \\
\text { parameters and } \\
\text { consequently } \\
\text { procured a model } \\
\text { to benchmark the } \\
\text { service providers in } \\
\text { India }\end{array}$ & In one country & $\begin{array}{l}\text { With regard to the } \\
\text { efficiency analysis, } \\
\text { benchmark may can be } \\
\text { adjusted, and obtaining } \\
\text { utility efficiency scores } \\
\text { would be feasible on } \\
\text { the basis of a set of } \\
\text { benchmarks. Therefore, } \\
\text { the scores could enable } \\
\text { the development of } \\
\text { a strategic plan to } \\
\text { diminish the parameters } \\
\text { involving in the system } \\
\text { inefficiency }\end{array}$ \\
\hline $\begin{array}{l}\text { Karbassi } \\
\text { Yazdi } \\
\text { and } \\
\text { Abdi } \\
(2017)\end{array}$ & $\begin{array}{l}\text { Intended for } \\
\text { determining the } \\
\text { most acceptable } \\
\text { banks with regard } \\
\text { to the predefined } \\
\text { indices }\end{array}$ & $\begin{array}{l}\text { In a number of } \\
\text { cases, the outputs } \\
\text { and inputs had } \\
\text { higher priority } \\
\text { for DMs in } \\
\text { comparison to the } \\
\text { others; therefore, } \\
\text { it would need a } \\
\text { series of variations. } \\
\text { Moreover, if one of } \\
\text { input or output has } \\
\text { been greater than } \\
\text { the others, DMU } \\
\text { became efficient } \\
\text { in spite of its low } \\
\text { priority. Hence, } \\
\text { their study indices } \\
\text { have been ranked by } \\
\text { Rembrandt method } \\
\text { in order to resolve } \\
\text { the above problem }\end{array}$ & $\begin{array}{l}\text { Evaluation of bank } \\
\text { performance with } \\
\text { regard to a limited } \\
\text { set of variables }\end{array}$ & $\begin{array}{l}\text { A number of the outputs } \\
\text { as well as inputs have } \\
\text { been prioritized for } \\
\text { banks in comparison } \\
\text { to the others; thus, it } \\
\text { would need a number of } \\
\text { variations in the coming } \\
\text { years }\end{array}$ \\
\hline $\begin{array}{l}\text { Álvarez- } \\
\text { Rodrí- } \\
\text { guez } \\
\text { et al. } \\
(2019)\end{array}$ & $\begin{array}{l}\text { Combined use } \\
\text { DEA and Life } \\
\text { Cycle Evaluation } \\
\text { for environmental } \\
\text { and operational } \\
\text { benchmarking in } \\
\text { the service sectors }\end{array}$ & $\begin{array}{l}\text { The LCA + DEA } \\
\text { method reflected } \\
\text { higher potency } \\
\text { in advocating the } \\
\text { decision-makers } \\
\text { like the managers } \\
\text { of a company } \\
\text { while defining } \\
\text { accurate targets } \\
\text { for environmental } \\
\text { and operational } \\
\text { improvements in } \\
\text { the grocery stores in } \\
\text { the service sector }\end{array}$ & $\begin{array}{l}\text { Only have } \\
\text { investigated } \\
\text { groceries located in } \\
\text { Spain }\end{array}$ & $\begin{array}{l}\text { Nevertheless, national } \\
\text { policymakers can take } \\
\text { advantage from this } \\
\text { kind of methodological } \\
\text { solution for setting the } \\
\text { threshold values for an } \\
\text { efficient utilization and } \\
\text { sustainable management } \\
\text { of the resources in the } \\
\text { service sectors }\end{array}$ \\
\hline
\end{tabular}




\subsection{Product planning}

Braglia et al. (2003) comprehensively examined the performance of five steel factories in a largest private group in Italy. Therefore, the present investigation proposed a new method for determining the efficiency of the plant was proposed, which could help to manage the production strategies based on their performance, usually in industrial environments. In this study, the studies were performed according to the DEA method. In addition, it was enhanced by the use of several modified solutions that were proposed in previous texts. The results were sorted using a suitable cluster analysis. Finally, a technical and economic analysis was proposed for inefficient production units. The proposed model in the industrial unit was used as a reference, which means it can also be used or generalized in other manufacturing areas.

For example, Trappey and Chiang (2008) used DEA framework to develop a management approach and benchmarking planning to maximize activities of new product development (NPD) into a profit center in order to reach the full benefit goal and fulfill the resource constraints. They proposed a new method for NPD's strategic benchmarking, with regard to the business model of the decentralized profit centers, to implement an effective NPD decision making and planning method for profit center managers. The most important component of this approach is the access to NPD activity information, which can easily be found in the industrial companies where NPD projects are fully implemented. Finally, by implementing a realistic model for motorcycle design, this study showed that DEA-based meta-measurements are sufficiently effective for planning NPD projects under the Center model.

Shabanpour et al. (2017) used robust DEA double frontiers and target programming to the further study plans to benchmark and rank the sustainable suppliers. They also proposed a program to improve productivity in order to rank suppliers with a stable and selection criterion. For suppliers, the two levels of the program, which included targets and benchmarks, were presented. To achieve this goal, targets at the first level are determined by target programming (GP) and DEA. Because the inputs and outputs are likely to be unknown at first level targets, the Charnes-Cooper-Rhodes (CCR) boost model was used. After identifying the second level criteria, a modified CCR inefficiency model was used to determine the supplier's rank. Actually, this ranking feature is created by the creation of a dual boundary that includes the inefficient and efficient boundaries of CCR. Accordingly, suppliers were ranked with the use of the first level objectives. According to the new ranking, the targets uncertainties have been determined by the implementation of optimization methods. Their new method provided planning and technical features that have been illustrated by a case study.

We reviewed 3 articles related to product planning analyzed. After reviewing the main advantages and disadvantages of each article, it is summarized in Table 3.

\subsection{Maintenance}

Gouveia et al. (2015) presented a study on benchmarking analysis related to maintenance activities done by a Portuguese Electricity Distribution Co., EDP Distribution (EDP-D). In this study, relationship between DEA and MCDA was evaluated using a value-based DEA method. Their paper examined impact of applying management priorities on the classification and ranking of the 40 network domains covered by EDP-D. The findings were consistent 
with the outputs presented by earlier BCC / DEA model. Therefore, to avoid uncertainty, value-based DEA-based approach to evaluate the performance has been adopted to incorporate the notion "superior performance". Moreover, researchers, identified the most reasonable practices, inefficient resources, opportunities for improvements, gaps in the most acceptable practices, and supported corrective actions and decision-making on the future objectives and promotion of information of the company.

Table 3. Summarizes the advantages and disadvantages of the product planning articles

\begin{tabular}{|c|c|c|c|c|}
\hline Author & Main Idea & Advantage & Disadvantage & $\begin{array}{l}\text { Main suggestion } \\
\text { for future research }\end{array}$ \\
\hline $\begin{array}{l}\text { Braglia et al. } \\
\text { (2003) }\end{array}$ & $\begin{array}{l}\text { Their proposed } \\
\text { method to } \\
\text { measure the plant } \\
\text { performance } \\
\text { could enable } \\
\text { managing in the } \\
\text { formulation of the } \\
\text { manufacturing } \\
\text { approaches }\end{array}$ & $\begin{array}{l}\text { This new } \\
\text { method has been } \\
\text { substantially utilized } \\
\text { to the industrial } \\
\text { cases of reference } \\
\text { and thus it may be } \\
\text { readily extended to } \\
\text { each manufacturing } \\
\text { setting }\end{array}$ & $\begin{array}{l}\text { For a company } \\
\text { with poor } \\
\text { operation, with } \\
\text { the general } \\
\text { characteristic of the } \\
\text { inefficient plants, } \\
\text { DEA analysis may } \\
\text { not work. } \\
\text { Therefore, each } \\
\text { plant should be } \\
\text { ameliorated; that is, } \\
\text { the plants should } \\
\text { have efficiency of } 1 .\end{array}$ & $\begin{array}{l}\text { For resolving } \\
\text { this limitation, } \\
\text { researchers may } \\
\text { propose a fictitious } \\
\text { series of references } \\
\text { described by very } \\
\text { good values with } \\
\text { regard to the } \\
\text { investigated outputs } \\
\text { and inputs }\end{array}$ \\
\hline $\begin{array}{l}\text { Trappey } \\
\text { and Chiang } \\
\text { (2008) }\end{array}$ & $\begin{array}{l}\text { Employs DEA } \\
\text { notion for } \\
\text { presenting a } \\
\text { benchmarking plan } \\
\text { and management } \\
\text { procedure for } \\
\text { optimizing the } \\
\text { NPD activity into } \\
\text { a profit center } \\
\text { for achieving } \\
\text { objectives of the } \\
\text { greatest profit } \\
\text { and satisfaction } \\
\text { of resource } \\
\text { restrictions }\end{array}$ & $\begin{array}{l}\text { Using the actual } \\
\text { case of electric } \\
\text { motor scooter } \\
\text { design project, their } \\
\text { study demonstrated } \\
\text { considerable } \\
\text { efficiency of DEA } \\
\text { benchmarking for } \\
\text { NPD }\end{array}$ & $\begin{array}{l}\text { Don't advocate } \\
\text { strategic planning } \\
\text { and management } \\
\text { of the derivative } \\
\text { NPD with regard } \\
\text { to the profit-center } \\
\text { business model }\end{array}$ & $\begin{array}{l}\text { Applying this } \\
\text { research approach } \\
\text { to similar industries } \\
\text { can be an idea for } \\
\text { future research }\end{array}$ \\
\hline $\begin{array}{l}\text { Shabanpour } \\
\text { et al. (2017) }\end{array}$ & $\begin{array}{l}\text { Presented } \\
\text { an efficiency } \\
\text { improvement } \\
\text { program for } \\
\text { ranking the } \\
\text { sustainable } \\
\text { suppliers and } \\
\text { selecting the } \\
\text { benchmark }\end{array}$ & $\begin{array}{l}\text { By implementing } \\
\text { their strategy } \\
\text { decision maker } \\
\text { identified efficient } \\
\text { and inefficient } \\
\text { suppliers and } \\
\text { recognized the } \\
\text { future inefficiency } \\
\text { of the suppliers. } \\
\text { Therefore, managers } \\
\text { may stop additional } \\
\text { loss by planning } \\
\text { and making the } \\
\text { preventing decision }\end{array}$ & $\begin{array}{l}\text { Limited research } \\
\text { scope can be one of } \\
\text { the limitations of } \\
\text { this research }\end{array}$ & $\begin{array}{l}\text { Similar } \\
\text { investigations may } \\
\text { be iterated for other } \\
\text { decision-making } \\
\text { issues like selection } \\
\text { of technology and } \\
\text { product in the } \\
\text { presence of fuzzy } \\
\text { information }\end{array}$ \\
\hline
\end{tabular}


Assaf et al. (2015) measured the relative efficiency of the maintenance unit at a main petro-chemical company in Saudi Arabia. In this study, using an EMS system, an output metric and three input criteria were determined. The DEA method was used in this study. Data from 23 maintenance units were collected and analyzed during 6 months. Using this study, operational units with low efficiency and high efficiency were identified. The most important feature of their research has been the examination of the functions of the multiple inputs and outputs simultaneously. This study provided important and valuable information from the unit's function to the maintenance department managers and decision makers. The study recommends that rehabilitation work processes be re-evaluated and studied. The study also suggests that scheduling should be started six weeks before the operation is completed to provide all the necessary resources, workforce, as well as spare parts. In addition, all preventive maintenance measures are recommended to ensure accurate human resources estimation and task synchronization, and to be assured of PMR.

We reviewed 2 articles related to maintenance reviewed. After reviewing the main advantages and disadvantages of each article, it is summarized in Table 4.

Table 4. Summarizes the advantages and disadvantages of the maintenance articles

\begin{tabular}{|c|c|c|c|c|}
\hline Author & Main Idea & Advantage & Disadvantage & $\begin{array}{l}\text { Main suggestion } \\
\text { for future research }\end{array}$ \\
\hline $\begin{array}{l}\text { Gouveia } \\
\text { et al. } \\
\text { (2015) }\end{array}$ & $\begin{array}{l}\text { Presented a } \\
\text { benchmarking } \\
\text { investigation for } \\
\text { maintenance and } \\
\text { outage repair activity } \\
\text { performed by a } \\
\text { Portuguese electricity } \\
\text { distribution Co., } \\
\text { EDP Distribuição } \\
\text { (EDP-D). The use of } \\
\text { Value-Based DEA } \\
\text { method linked with } \\
\text { Multiple Criteria } \\
\text { Decision Analysis } \\
\text { (MCDA) }\end{array}$ & $\begin{array}{l}\text { Exploited outcomes } \\
\text { of the use of Value- } \\
\text { Based DEA for } \\
\text { a similar set of } \\
\text { information. } \\
\text { Allowed for } \\
\text { incorporating the } \\
\text { managerial priorities } \\
\text { for identifying the } \\
\text { most acceptable } \\
\text { practices }\end{array}$ & $\begin{array}{l}\text { Just one DM } \\
\text { has been } \\
\text { interviewed } \\
\text { during the } \\
\text { elicitation } \\
\text { procedure } \\
\text { of the utility } \\
\text { function and } \\
\text { introduction } \\
\text { of the weight } \\
\text { constraints }\end{array}$ & $\begin{array}{l}\text { Besides identification } \\
\text { of the most acceptable } \\
\text { practices, resources of } \\
\text { inefficiency, the gaps } \\
\text { relative to the most } \\
\text { acceptable practices } \\
\text { and chances for } \\
\text { improvements, we can } \\
\text { support the introduction } \\
\text { of the corrective measures } \\
\text { and announce decisions of } \\
\text { the future objectives, and } \\
\text { improve insights into the } \\
\text { company }\end{array}$ \\
\hline $\begin{array}{l}\text { Assaf } \\
\text { et al. } \\
(2015)\end{array}$ & $\begin{array}{l}\text { Measured the } \\
\text { relative efficiency } \\
\text { of the maintenance } \\
\text { units into a main } \\
\text { petrochemical } \\
\text { company in Saudi } \\
\text { Arabia }\end{array}$ & $\begin{array}{l}\text { It employed the } \\
\text { available indices, } \\
\text { which have been put } \\
\text { together at all prior } \\
\text { to the provision } \\
\text { of a detailed } \\
\text { study of the unit } \\
\text { performance that } \\
\text { enabled the efficient } \\
\text { benchmarking. } \\
\text { Capability of the } \\
\text { evaluation of } \\
\text { performance of } \\
\text { several outputs and } \\
\text { inputs at the same } \\
\text { time in an objective } \\
\text { manner }\end{array}$ & $\begin{array}{l}\text { Does not } \\
\text { review work } \\
\text { management } \\
\text { process }\end{array}$ & $\begin{array}{l}\text { It is recommended to } \\
\text { begin the planning and } \\
\text { scheduling six weeks } \\
\text { ahead of the work } \\
\text { implementation for } \\
\text { preparing each necessary } \\
\text { resource, spare part as } \\
\text { well as workforce for } \\
\text { avoiding under-utilization } \\
\text { of the workforce. } \\
\text { Moreover, coordination } \\
\text { of each preventive } \\
\text { maintenance job would } \\
\text { be recommended for } \\
\text { assuring the precise } \\
\text { approximation of the } \\
\text { workforce. }\end{array}$ \\
\hline
\end{tabular}




\subsection{Hotel industry}

Assaf (2012) conducted a benchmarking study of Asia Pacific hotel as well as the tour operator industry. They utilized an innovative approach focused on the combination of stochastic frontier and DEA within a Bayes system. The results showed that Singapore, South Korea, and Australia have been introduced as the most efficient ones in their tour operator and hotel industries.

Wu et al. (2013) presented a benchmarking framework to assess the hotel industry efficiency in several periods, with consideration of depreciable characteristics and transitional activities. In the study, high performance functions have been specified and their business approaches have been illustrated. Dynamic DEA was used to identify stable efficient functions. An excellent DEA method was used for overall ranking of input-output-consumption structure. A further analysis has been also accomplished to facilitate the interpretation of the outcomes of benchmarking. Totally, 9 hotels from 80 international tourist hotels in Taiwan from 2006 to 2010 were recognized as high-efficiency hotels. These hotels offer business strategies for the staff (intensive vs. economical workforces), product (the room vs. F\&B services (food \& drink), price (very costly and highly cheap prices), guest (e.g., business and tourism guests) and so forth; for example, location supremacy have been divergent.

We reviewed 2 articles identified as hotel industry. After reviewing the main advantages and disadvantages of each article, it is summarized in Table 5.

Table 5. Summarizes the advantages and disadvantages of the hotel industry articles

\begin{tabular}{|l|l|l|l|l|}
\hline Author & \multicolumn{1}{|c|}{ Main Idea } & \multicolumn{1}{c|}{ Advantage } & \multicolumn{1}{c|}{ Disadvantage } & \multicolumn{1}{c|}{$\begin{array}{c}\text { Main suggestion } \\
\text { for future research }\end{array}$} \\
\hline $\begin{array}{l}\text { Assaf } \\
(2012)\end{array}$ & $\begin{array}{l}\text { Measured and } \\
\text { compare efficiency } \\
\text { of the leading } \\
\text { tour operator and } \\
\text { hotel companies } \\
\text { throughout } \\
\text { numerous Asia } \\
\text { Pacific countries } \\
\text { the innovative } \\
\text { on the } \\
\text { basis of the } \\
\text { combination of } \\
\text { the stochastic } \\
\text { frontier and } \\
\text { DEA in a Bayes } \\
\text { framework }\end{array}$ & $\begin{array}{l}\text { Used one of } \\
\text { then major limitation has } \\
\text { the sample in a number } \\
\text { of countries. Number of } \\
\text { years has been limited. } \\
\text { Hence, outcomes may } \\
\text { be impacted by current } \\
\text { directions such the } \\
\text { recent financial crisis }\end{array}$ & $\begin{array}{l}\text { As a result of limitations } \\
\text { in data, more hotels } \\
\text { number of countries in } \\
\text { than other ones may can } \\
\text { be obtained. Therefore, } \\
\text { efficiency for each sample } \\
\text { individually did not } \\
\text { estimate and comparison } \\
\text { must be done carefully }\end{array}$ \\
\hline $\begin{array}{l}\text { Wu } \\
\text { et al. } \\
(2013)\end{array}$ & $\begin{array}{l}\text { Introduced a } \\
\text { benchmarking } \\
\text { method to assess } \\
\text { efficiency of hotel } \\
\text { industries, in a } \\
\text { multiperiod setting } \\
\text { by examining the } \\
\text { perishable features } \\
\text { as well as the } \\
\text { carry-over activity }\end{array}$ & $\begin{array}{l}\text { Involved in the } \\
\text { benchmarking } \\
\text { articles and } \\
\text { hotel industry } \\
\text { in multiple } \\
\text { dimensions }\end{array}$ & $\begin{array}{l}\text { Analysis of the } \\
\text { variations in the } \\
\text { most acceptable } \\
\text { hotel practices via } \\
\text { comparison of the } \\
\text { benchmarking } \\
\text { outcomes between 2 } \\
\text { distinct multiperiod } \\
\text { timetables; for example, } \\
\text { from 2006 to 2008 vs. } \\
\text { 2009 to 2011 }\end{array}$ & $\begin{array}{l}\text { Their suggestion } \\
\text { for applying this } \\
\text { new multiperiod } \\
\text { benchmarking method to } \\
\text { other service industries } \\
\text { like the transportation } \\
\text { system described with } \\
\text { perishable and carry- } \\
\text { over activities in further } \\
\text { investigations }\end{array}$ \\
\hline
\end{tabular}




\subsection{Education}

In this regard, Reichmann and Sommersguter-Reichmann (2006) presented a structure for evaluating technological output in Austria, Australia, Germany, Canada, Switzerland, US of 118 university libraries. The DEA method has been used to investigate and evaluate the difference between those libraries' results. They also looked at how the internal organizational rules influenced the productivity of libraries. Findings of the performance appraisal between countries indicate that nearly $1 / 3$ of the university libraries were efficient. With the use of the particular environmental boundaries, the difference in managerial efficiency versus the difference in environmental productivity was examined, reflecting the major discrepancies in the technical efficiencies of the European as well as non-European academic libraries. Nevertheless, according to environmental laws, non-European libraries with the highest performance are better than their European ones.

In addition, Gourishankar and Sai Lokachari (2012) used the Educational Development Efficiency (EDE) model for benchmarking the country states. In this paper, a conceptual framework for input-process-output was used for identifying educational development aspects. In their investigation, researchers utilized DEA model to compare relative efficacy and benchmarking of 28 states and 7 areas in India. In fact, factor analysis has been used for determining relationship between existing variables. Using multiple regression analysis, effective effectiveness variables were identified. In their study, the benchmarking of the educational development in the Indian states was carried out according to their performance. By examining the results, it was found that the variables that affected state EDE were the ratio of gross participation, students' academic performances and infrastructure investment. Insights into the use of input tools to enhance the quality of education and the later improvements in the state efficiency have been provided. Hence, 4 elements were established to evaluate progress of the educational achievement of the states; that is, financial sufficiency, strength of the school infrastructure, quality of education and access to education.

Cook et al. (2017) proposed a method to study the status of Spanish universities (where the current policies of universities are highly influenced and affiliated with regional governments), and was inspired by studies by Cook and Zhu (2007) to benchmark DMUs that members have same conditions. According to Cook and Zhu (2007), in these cases, a DEA-based strategy, which independently evaluates DMU behaviors is not very effective. The common criteria within the group presented in their study can be considered as a mediator between the common complete benchmarking test and pure DEA for entire DMU set. This approach is on the basis of the Pareto-efficient DEA method, which is determined by a set of DMUs, and supposed to be compared. Such a method has specifically prevented the occurrence of problems in small DMU groups. Empirical observations indicate that the proposed method can produce results that better reflect the conditions of DMUs. Especially when these DMUs are under a same benchmarking.

Ramón et al. (2018) presented a 2-phase benchmarking process in context-dependent DEA model and models that minimize their gap from the efficient DEA model. This method allows us to determine the realistic goals that are achievable, within a short time. In addition, various alternatives may be introduced to plan the progress towards the goals of the effective DEA model, which can be indicative of long-term improvement. Consequently, this 
continuous approach provides managers with tools for deciding on ongoing reform strategies based on their operational objectives. This is possible by gaining experience from expertise and efficient systems. The research output of the Spanish public universities was analyzed to demonstrate this approach as an example. Given the respective utility, many ways exist to improve the suggested solution. One of the attractive lines of researches must be aimed at the investigation of expansion of a 2-phase benchmarking method for addressing the targeted DEA models that have been utilized in several practical analytical utilizations. We reviewed 4 articles related to education verified. After reviewing the main advantages and disadvantages of each article, it is summarized in Table 6.

Table 6. Summarizes the merits and caveats of education articles

\begin{tabular}{|c|c|c|c|c|}
\hline Author & Main Idea & Advantage & Disadvantage & $\begin{array}{l}\text { Main suggestion } \\
\text { for future research }\end{array}$ \\
\hline $\begin{array}{l}\text { Reichmann } \\
\text { and Som- } \\
\text { mersguter- } \\
\text { Reichmann } \\
\text { (2006) }\end{array}$ & $\begin{array}{l}\text { A DEA framework } \\
\text { for international } \\
\text { performance } \\
\text { evaluation of } 118 \\
\text { university libraries } \\
\text { consisting of libraries } \\
\text { from Austria, } \\
\text { Australia, Germany, } \\
\text { Canada, US, } \\
\text { Switzerland }\end{array}$ & $\begin{array}{l}\text { Providing the initial } \\
\text { information of } \\
\text { technical efficiency } \\
\text { differential at the level } \\
\text { of library and at a } \\
\text { more aggregate level }\end{array}$ & $\begin{array}{l}\text { Qualities } \\
\text { of the DEA } \\
\text { outputs } \\
\text { depended } \\
\text { strongly } \\
\text { upon the } \\
\text { selection of } \\
\text { the output } \\
\text { and input } \\
\text { measures }\end{array}$ & $\begin{array}{l}\text { Because any } \\
\text { information has been } \\
\text { not found about in- } \\
\text { library use, outputs } \\
\text { can be distorted } \\
\text { systematically. } \\
\text { Measures associated } \\
\text { with quality like the } \\
\text { satisfaction, user- } \\
\text { friendliness and or } \\
\text { responsiveness must } \\
\text { be considered }\end{array}$ \\
\hline $\begin{array}{l}\text { Gourishankar } \\
\text { and Sai } \\
\text { Lokachari } \\
(2012)\end{array}$ & $\begin{array}{l}\text { Develops an } \\
\text { EDE model for } \\
\text { benchmarking the } \\
\text { Indian states }\end{array}$ & $\begin{array}{l}\text { Information of the } \\
\text { application of the } \\
\text { input resources } \\
\text { for enhancing } \\
\text { the educational } \\
\text { development as well } \\
\text { as later improvements } \\
\text { in the state efficiencies } \\
\text { have been offered }\end{array}$ & $\begin{array}{l}\text { Research } \\
\text { in a one } \\
\text { geographic } \\
\text { area can be a } \\
\text { limitation }\end{array}$ & $\begin{array}{l}\text { Offer Indian states } \\
\text { a cross-comparison } \\
\text { for performance } \\
\text { benchmarking } \\
\text { purposes with other } \\
\text { countries }\end{array}$ \\
\hline $\begin{array}{l}\text { Cook et al. } \\
\text { (2017) }\end{array}$ & $\begin{array}{l}\text { A strategy to } \\
\text { benchmark the } \\
\text { DMUs, which may } \\
\text { be placed within } \\
\text { the groups whose } \\
\text { members experienced } \\
\text { the same situation }\end{array}$ & $\begin{array}{l}\text { The models have } \\
\text { been designed for } \\
\text { conditions wherein } \\
\text { a popular best- } \\
\text { practice frontier has } \\
\text { been specified for a } \\
\text { group of DMUs as } \\
\text { a consequence of } \\
\text { choosing dimensions, } \\
\text { which yielded the } \\
\text { closest targets }\end{array}$ & $\begin{array}{l}\text { Due to lack } \\
\text { of individual } \\
\text { situations of } \\
\text { universities } \\
\text { into the } \\
\text { regions }\end{array}$ & $\begin{array}{l}\text { Evaluation of } \\
\text { research performance } \\
\text { of university of other } \\
\text { countries }\end{array}$ \\
\hline $\begin{array}{l}\text { Ramón et al. } \\
\text { (2018) }\end{array}$ & $\begin{array}{l}\text { Proposing a 2-step } \\
\text { benchmarking } \\
\text { strategy in the spirit } \\
\text { of context-dependent } \\
\text { DEA and the models } \\
\text { minimizing distance } \\
\text { to the DEA efficient } \\
\text { frontier }\end{array}$ & $\begin{array}{l}\text { Considering outputs } \\
\& \text { inputs presented } \\
\text { below that related as } \\
\text { usual to the physical } \\
\text { and human capital } \\
\text { and incomes and } \\
\text { publications }\end{array}$ & $\begin{array}{l}\text { Only in } \\
\text { public } \\
\text { Spanish } \\
\text { universities }\end{array}$ & $\begin{array}{l}\text { Perform at other } \\
\text { universities and } \\
\text { educational } \\
\text { institutions }\end{array}$ \\
\hline
\end{tabular}




\subsection{Distribution}

Jha et al. (2008) used updated DEA models to test benchmarking of the production and distribution units in Nepal. They studied operating efficiency of the producing stations and Nepal Electricity Authority (NEA) owned distribution centers. These models contain a broad variety of outputs as well as inputs, which reflect the nature of processes in question. DMU rating was provided based on their overall average output score.

Ajodhia (2010) stated that energy regulators, using price-capping system, usually did not use quality in the procedure of benchmarking. Hence, the present investigation aimed at the explanation of a technique for the integrated quality-cost benchmarking in the networks of the electricity distribution. Therefore, 2 fundamental models were used in the study: a technical model that minimizes quality as an input variable and a social cost model that measured quality of an optimal presentation. The two models were used in two Dutch and English companies. The results showed that although the integrated quality-price benchmarking is an important indicator in the regulation of rules, but also its limitations should be identified.

Hung Lau (2012) discussed utilization of DEA model to assess performance of the store with the aim of correcting the distribution network in his study. A DEA model was utilized for examining relative efficiency of the distribution in main stores of a key retailer in Australia. The present investigation was conducted using other methods like spatial distribution of demand and customer segmentation, and showed the DEA method was able to provide a rational and appropriate justification for the distribution network. This method can also be used as an analytical method to facilitate continuous improvement. The result showed that when retail stores are closed down or merged with other stores operating in similar areas, the overall network performance will improve. Such logical actions will result in the integration of demands and modification of the operation of vehicles with minimal impact on customer service.

We reviewed 3 articles related to distribution recognized. After reviewing the main advantages and disadvantages of each article, it is summarized in Table 7.

Table 7. Summarizes the advantages and disadvantages of the distribution articles

\begin{tabular}{|l|l|l|l|l|}
\hline Author & \multicolumn{1}{|c|}{ Main Idea } & \multicolumn{1}{|c|}{ Advantage } & Disadvantage & $\begin{array}{l}\text { Main suggestion } \\
\text { for future research }\end{array}$ \\
\hline $\begin{array}{l}\text { Jha et al. } \\
\text { (2008) }\end{array}$ & $\begin{array}{l}\text { To investigate the } \\
\text { operational efficiency of } \\
\text { the generating stations } \\
\text { and the distribution } \\
\text { center (DCS) owned } \\
\text { by Nepal Electricity } \\
\text { Authority (NEA) }\end{array}$ & $\begin{array}{l}\text { The DMUs has been } \\
\text { ranked on the basis of } \\
\text { their average overall } \\
\text { efficiency score }\end{array}$ & $\begin{array}{l}\text { Limited of } \\
\text { the variables } \\
\text { under study }\end{array}$ & $\begin{array}{l}\text { Select more } \\
\text { variable of power } \\
\text { plants }\end{array}$ \\
\hline $\begin{array}{l}\text { Ajodhia } \\
(2010)\end{array}$ & $\begin{array}{l}\text { Developed a method } \\
\text { for the integrated cost- } \\
\text { quality benchmarking } \\
\text { for the electricity } \\
\text { distribution network }\end{array}$ & $\begin{array}{l}\text { There is no completely } \\
\text { integrated price-quality } \\
\text { benchmarking strategy for } \\
\text { the electricity distribution } \\
\text { networks; therefore, } \\
\text { this research filled the } \\
\text { mentioned gap }\end{array}$ & $\begin{array}{l}\text { The two } \\
\text { models were } \\
\text { used only in } \\
\text { two Dutch } \\
\text { and English } \\
\text { companies }\end{array}$ & $\begin{array}{l}\text { Implementation in } \\
\text { other companies }\end{array}$ \\
\hline
\end{tabular}


End of Table 7

\begin{tabular}{|l|l|l|l|l|}
\hline Author & \multicolumn{1}{|c|}{ Main Idea } & \multicolumn{1}{|c|}{ Advantage } & Disadvantage & $\begin{array}{l}\text { Main suggestion } \\
\text { for future research }\end{array}$ \\
\hline $\begin{array}{l}\text { Hung } \\
\text { Lau } \\
(2012)\end{array}$ & $\begin{array}{l}\text { Discussed the use of } \\
\text { DEA for benchmarking } \\
\text { the store performances } \\
\text { in order to rationalizing } \\
\text { the retail distribution } \\
\text { network }\end{array}$ & $\begin{array}{l}\text { Their strategy may } \\
\text { contribute to selection } \\
\text { of the most reasonable } \\
\text { practice and facilitation of } \\
\text { more efficient allocation of } \\
\text { the resources through the } \\
\text { whole retail network. } \\
\text { Moreover, the approach } \\
\text { adds further knowledge of } \\
\text { how demand management } \\
\text { may influence the } \\
\text { distribution efficiency of } \\
\text { the retail network }\end{array}$ & $\begin{array}{l}\text { The research } \\
\text { has been } \\
\text { limited to } \\
\text { the retail } \\
\text { network with } \\
\text { a relative } \\
\text { function in } \\
\text { distributing } \\
\text { assessed } \\
\text { on a single } \\
\text { input and a } \\
\text { single output } \\
\text { variable }\end{array}$ & $\begin{array}{l}\text { Expanding the } \\
\text { scope of research } \\
\text { for more stores }\end{array}$ \\
\hline
\end{tabular}

\subsection{Environment}

Liu et al. (2019) developed a range-adjusted measurement (RAM) efficiency metric focused on the farthest target that examined the unwanted production for the calculation of the environmental performance. DEA is used for determining environmental performance of 27 coal-fired power stations in China. Consequently, on the basis of the assumption that information of benchmarking information may provide a crucial path for inefficient DMUs for achieving efficiency, the other RAM environmental performance metric is designed to evaluate the output and provide the closest benchmarking information, with regard to the closest target. Therefore, empirical study showed that the closest goals would be easier to achieve and provided the most important solution for inefficiency reduction.

Didehkhani et al. (2019) have suggested the transformation of a non-linear model into a linear one with the correct transformations. In this paper, with the notion artificial DMUs, a practical DEA model has been proposed which considers the environmental and practical constraints. In addition, the model feasibility and bounded efficiency scores could be two merits of the model.

Das and Kundu (2019) determined the crucial parameters of the environment that influenced overall function of Micro Small Medium Enterprises (MSMEs). This research designed an efficiency score for all countries with regard to the interaction variable. As shown by the present study results, each of the countries working at suboptimal scale held the benchmark relationships with an efficient country, which has been operated at the optimized scale. Hence, it is necessary for the macro-economic policy-makers of the inefficient countries to emphasize the benchmark countries while formulating policies.

We reviewed 3 articles related to environment identified. After reviewing the main advantages and disadvantages of each article, it is summarized in Table 8. 
Table 8. Summarizes the advantages and disadvantages of the analyzed articles

\begin{tabular}{|l|l|l|l|l|}
\hline Author & \multicolumn{1}{|c|}{ Main Idea } & \multicolumn{1}{|c|}{ Advantage } & Disadvantage & \multicolumn{1}{|c|}{$\begin{array}{c}\text { Main suggestion } \\
\text { for future research }\end{array}$} \\
\hline $\begin{array}{l}\text { Liu et al. } \\
\text { (2019) }\end{array}$ & $\begin{array}{l}\text { DEA has been } \\
\text { utilized for the } \\
\text { evaluation of the } \\
\text { environmental } \\
\text { efficiency of } 27 \text { coal- } \\
\text { fred power plants in } \\
\text { China }\end{array}$ & $\begin{array}{l}\text { It demonstrates that } \\
\text { closest objectives } \\
\text { have been more } \\
\text { simply achievable } \\
\text { and provided the } \\
\text { most pertinent } \\
\text { solutions for } \\
\text { removing inefficiency }\end{array}$ & $\begin{array}{l}\text { Only one } \\
\text { country } \\
\text { studied }\end{array}$ & $\begin{array}{l}\text { The pollution emission } \\
\text { reduction allocation } \\
\text { amongst the coal-fired } \\
\text { power plants may be } \\
\text { one of the directions } \\
\text { for further studies }\end{array}$ \\
\hline $\begin{array}{l}\text { Didehkhani } \\
\text { et al. } \\
\text { (2019) }\end{array}$ & $\begin{array}{l}\text { Their article } \\
\text { attempted for } \\
\text { extending the } \\
\text { basic models to } \\
\text { benchmark the } \\
\text { efficient units at } \\
\text { functional condition }\end{array}$ & $\begin{array}{l}\text { Their model would } \\
\text { be constantly } \\
\text { practical. Moreover, } \\
\text { efficiency scores } \\
\text { have been attained at } \\
\text { thoroughly feasible } \\
\text { condition }\end{array}$ & $\begin{array}{l}\text { Only basic } \\
\text { models for } \\
\text { benchmarking } \\
\text { of efficient } \\
\text { units applied }\end{array}$ & $\begin{array}{l}\text { Taking into account } \\
\text { vagueness and the } \\
\text { environment of } \\
\text { functional limitations, } \\
\text { unknown strategies } \\
\text { like fuzzy, robust as } \\
\text { well as stochastic may } \\
\text { be utilized to suggest } \\
\text { future investigations }\end{array}$ \\
\hline $\begin{array}{l}\text { Das and } \\
\text { Kundu } \\
(2019)\end{array}$ & $\begin{array}{l}\text { Determining } \\
\text { essential parameters } \\
\text { of the environment } \\
\text { that impact overall } \\
\text { function of the } \\
\text { Micro-Small- } \\
\text { Medium Enterprises } \\
\text { (MSMEs) }\end{array}$ & $\begin{array}{l}\text { This investigation } \\
\text { devised one of the } \\
\text { efficiency scores } \\
\text { for all countries } \\
\text { with regard to the } \\
\text { interaction variable }\end{array}$ & $\begin{array}{l}\text { Two area } \\
\text { spotlighted }\end{array}$ & $\begin{array}{l}\text { The extended form } \\
\text { of the present } \\
\text { investigations may } \\
\text { be utilized for deeper } \\
\text { analyses of the policy } \\
\text { associated with MSMEs }\end{array}$ \\
\hline
\end{tabular}

\subsection{Other topics}

Díaz et al. (2004) applied benchmarking and DEA methods for the irrigation districts in Spain. This analysis has been utilized to identify the most representative irrigation areas in Andalusia that have been consequently examined comprehensively via application of the performance metrics chosen by IPTRID to be utilized in international benchmarking programs.

Wu et al. (2013) focused on Asian Games with more attention to the two main issues, the basis for common comparing for DMU ranking and a reference feasibility between inefficient DMUs and benchmarking goals. In their study, they developed previous studies related to DEA by providing an ameliorated context dependent DEA model. By the use of this model, a proper and specific ranking system has been created for each participating country. Their suggestion was to improve the ranking system in Asian games. As a result, more educational objectives were identified and as a result, participants who had poor performance were able to progressively improve their performance. The results of the study will be effective in improving the strategic management of decision making in sport.

Moreover, Oh and Shin (2015) examined the effects of the performance benchmarking mis-measurement: A Monte-Carlo analysis SFA and DEA with various multiperiod budgeting approaches. In the present article, outputs of the analyses are presented that contain errors in measuring and comparing efficiency of system in different empirical approaches. 
In each approach, a production frontier estimation model and a distinct multi-cycle budgeting approach are used. Boundary-estimation models that were used were the DEA model as well as stochastic frontier analysis (SFA). Principal outputs of this investigated included: (1) application of a budgeting approach and a proper benchmarking model may result in a significant increase in the system performance; (2) despite relatively high measurement errors, a "peanut butter" approach works better than a discriminative approach, while in cases where measurement errors are less, a discriminative strategy performs better; (3) frontier estimation models perform better than that of the randomly produced ranks models, even in cases where measurements with the comparatively large errors are faced; (4) in cases where measurement errors are low, the SFA model outperformed the DEA model, while DEA model performs better than SFA when measured with a large error.

Ruiz and Sirvent (2016) presented a DEA based strategy to benchmark and rank the decision makers. In manufacturing processes, many of situations that DMUs are involved in, are similar to each other, so benchmarking these situations leads to finding common problems and, therefore, adopts the most appropriate way to deal with them. Therefore, this method is used when there is no need to examine the DMU conditions individually. In other words, unlike DEA, the value of inputs and outputs must be shared among each unit that are being examined. However, in studies conducted, the DEA model was used to find the CSW for use in performance analysis, which suggests that it can be used to create a benchmarking framework. The approach proposed identifies a common boundary of the most appropriate measures as a form of DEA's efficiency boundary. This common boundary is produced by some DMUs in one of the common reference groups that has high technical capability. This reference group is selected to meet the most (closest) goals, diminishing gaps of the actual performance with the most acceptable procedures. Moreover, the extended model leads to the determination of CSWs that can be used to determine the amount of productivity and DMUs rank.

Mishra and Pal (2017) benchmarked India's SMEs through DEA so that they can predict their performance for effective decision making. For this purpose, there were 41 Indian SMEs that produce automotive parts. Similar groups and weights were identified in ineffective SMEs, which can be beneficial to benchmark ineffective DMUs. SMEs are able to find the factors that are weak and take appropriate measures to improve them. Similar groups in inefficient SMEs represent efficient SMEs that combine their inputs and outputs with many similarities. This tip helps managers to predict DMU performance individually with regard to the input consumption as well as produce "what-if" scenarios.

Wang (2017) examined the use of the DEA model, the measurement of environmentfriendly buildings and the identification of its separate advantages. At first, the methods and indicators for assessing the environmental performance standards were reviewed. Then, in order to implement individual and group benchmarking for a certain degree of "star", a model of benchmarking was performed with regard to the DEA model and identification of separate advantages. Finally, for modeling analysis, 15 specific projects were selected in the same region for determination of benchmarking similar projects. On basis of the creation of the DEA model, this investigation analyzed first validity of the green-building projects that function as a decision-making unit and consequently stated improvement paths for techni- 
cally inefficacious or invalid project scales; ultimately finds the learning benchmark provided with the all projects by identification of the individuality benefit. Zhou et al. (2019) investigated the compensation and penalty process based on a DEA benchmarking method for water resource environmental-carrying capacity (WRECC). Therefore, for proving validity of their new method, one of the case studies on WRECC-based PRM of top 10 cities in China's Huaihe River Basin has been chosen. Findings suggested that cities selected would be benchmarked as opposed to Yangzhou, Jining and Zhengzhou in 2016; Zhengzhou, Xuzhou. Yangzhou and Jining will earn reward and the rest of cities that have been assessed will impose penalties. The difference between the actual output and the DEA goals can be established according to the results; how much change those areas may be specified; and areas, which must be punished or rewarded a particular amount of the money expected may be specified.

Samoilenko and Osei-Bryson (2019) presented a modern multimethod method to benchmark, which obviously examined the context-specific parameters influencing the function of the of organizational entities. Such an approach entails creative integration of multiple information systems (IS), artifacts; that is, numerous data mining techniques with DEA. The results showed complexity of the association of the parameters, which show drivers and impacts.

Nasrabadi et al. (2019) presented a benchmarking algorithm to DEA with the intervalscale data. Their strategy has been on the basis of a layering process that classified a series of each unit to various layers based on their efficiency state. Conclude lies on two possible drawbacks. The first probable one is zigzagging; that is, an output or input variable can enhance in one phase and decline in another phase. As a result, the defined path would not experience a monotonic convergence to the final efficient objective. In addition, the amounts of the adjustment between 2 sequential objectives can differ; namely, 2 intermediate objectives can be highly close and include little alterations whereas for 2 other ones, considerable adjustments would be crucial. Hence, we cannot control the amounts of adjustment necessary in each phase in such layering algorithm. Nevertheless, regarding the interval scale data, such a concept would be highly advantageous in discovering the targeted units.

Ashuri et al. (2019) contributed to our information in creating the energy benchmarking using the modern DEA model. This modern DEA model has been utilized for benchmarking the energy efficiency in 108 buildings in a multi-family sector that considered parameters showing the total consumption of energy, building properties as well as local weather condition. It specified ineffective units via examining 3 efficiency scores; that is, pure technical efficiency, scale efficiency, and overall efficiency among the DMUs in a multi-family housing industry. Their outputs reflected that about $20 \%$ of the features actually have been activating at the most productive scale sizes as $100 \%$ efficient with regard to the pure technical efficiency. The above result indicated management of the features in a more energy-efficient way by the facility managers in those buildings.

Ruiz and Sirvent (2020) argued incorporation of the DEA benchmarking models into their objective criteria in order to choose the proper benchmarks amongst peers and consideration of the definition of pleasant objectives. However, the strategy suggested in the present article intended for developing the DEA benchmarking models, which aimed to set proper objectives and identify the peers after favorable criteria to select the benchmarks. In 
particular, these models had two targets of defining the closest objectives and choosing the closest reference sets. Hence, outputs of this empirical utilization showed that the models practically specify the reference sets frequently containing the peers with functions of higher similarity with the unit being evaluated in comparison with the ones offered by the models, which just relate to the definition of the closest objectives.

Ramón et al. (2020) indicated the way of implementation of such a fundamental idea via the notion of cross benchmarking that has been considered to be one of the approaches designed into DEA framework. The outputs obtained from empirical applications illustrated a reality that managers can define their plans to improve via selection amongst the other plans following the consideration of various implications of the reduced input sources and or increased output production as well as reallocation of the resources or substitution of the outputs and inputs.

We reviewed 12 articles with different topic identified. After reviewing the main advantages and disadvantages of each article, it is summarized in Table 9.

Table 9. Summarizes the advantages and disadvantages of different articles

\begin{tabular}{|c|c|c|c|c|}
\hline Author & Main Idea & Advantage & Disadvantage & $\begin{array}{l}\text { Main suggestion } \\
\text { for future research }\end{array}$ \\
\hline $\begin{array}{l}\text { Díaz } \\
\text { et al. } \\
\text { (2004) }\end{array}$ & $\begin{array}{l}\text { Application of } \\
\text { benchmarking and } \\
\text { DEA methods in } \\
\text { Spanish irrigation } \\
\text { districts }\end{array}$ & $\begin{array}{l}\text { Allowing managers } \\
\text { to get a well-defined } \\
\text { rating of results. } \\
\text { These studies can } \\
\text { be very useful for } \\
\text { managers who } \\
\text { must often choose } \\
\text { between reducing } \\
\text { labor input or water } \\
\text { consumption or } \\
\text { substituting current } \\
\text { crops for more } \\
\text { profitable ones in } \\
\text { a given irrigation } \\
\text { district }\end{array}$ & $\begin{array}{l}\text { The DEA } \\
\text { study imitated } \\
\text { for five areas } \\
\text { representative } \\
\text { irrigation } \\
\text { districts of } \\
\text { Andalusia }\end{array}$ & $\begin{array}{l}\text { Expand the areas of } \\
\text { research }\end{array}$ \\
\hline $\begin{array}{l}\text { H. Wu } \\
\text { et al. } \\
(2013)\end{array}$ & $\begin{array}{l}\text { Extended earlier } \\
\text { DEA investigations } \\
\text { by incorporating an } \\
\text { enhancing context } \\
\text { dependent DEA } \\
\text { model, wherein the } \\
\text { empirical findings } \\
\text { for all participants } \\
\text { create a specific } \\
\text { and equal ranking } \\
\text { system }\end{array}$ & $\begin{array}{l}\text { Contributed to } \\
\text { the Asian Games } \\
\text { through more } \\
\text { questions about } 2 \\
\text { key problems; that } \\
\text { is, general basis to } \\
\text { rating DMUs as } \\
\text { well as comparison } \\
\text { feasibility between } \\
\text { ineffective } \\
\text { DMUs and their } \\
\text { benchmarking } \\
\text { targets }\end{array}$ & $\begin{array}{l}\text { It may not be } \\
\text { practical to } \\
\text { assume that the } \\
\text { weight limits on } \\
\text { the output items } \\
\text { use smoothly } \\
\text { throughout } \\
\text { each nation and } \\
\text { region }\end{array}$ & $\begin{array}{l}\text { Follow-up studies are } \\
\text { recommended to perform } \\
\text { relevant work in this area } \\
\text { of study }\end{array}$ \\
\hline
\end{tabular}


Continue of Table 9

\begin{tabular}{|c|c|c|c|c|}
\hline Author & Main Idea & Advantage & Disadvantage & $\begin{array}{l}\text { Main suggestion } \\
\text { for future research }\end{array}$ \\
\hline $\begin{array}{l}\text { Oh and } \\
\text { Shin } \\
(2015)\end{array}$ & $\begin{array}{l}\text { The researchers } \\
\text { conducted Monte } \\
\text { Carlo analysis } \\
\text { for comparing a } \\
\text { general system } \\
\text { throughput } \\
\text { in different } \\
\text { experimental } \\
\text { scenarios produced } \\
\text { by pairing } \\
\text { different multi } \\
\text { period budgeting } \\
\text { approaches with } 2 \\
\text { frontier estimation } \\
\text { models of output, } \\
\text { DEA, \& SFA }\end{array}$ & $\begin{array}{l}\text { Every scenario } \\
\text { assumes a particular } \\
\text { budgeting strategy } \\
\text { for multiple periods } \\
\text { and the production } \\
\text { frontier estimation } \\
\text { model }\end{array}$ & $\begin{array}{l}\text { In industry, } \\
\text { the expectation } \\
\text { of the use } \\
\text { of the same } \\
\text { measurement } \\
\text { error distribution } \\
\text { and inefficiency } \\
\text { distribution } \\
\text { would be feasible } \\
\text { during time } \\
\text { because it could } \\
\text { be conceived that } \\
\text { distribution of } \\
\text { the measurement } \\
\text { error and } \\
\text { inefficiency, } \\
\text { which } \\
\text { dynamically alter } \\
\text { as time goes }\end{array}$ & $\begin{array}{l}\text { Future research could } \\
\text { extend the scope } \\
\text { of such a topic by } \\
\text { additionally exploring } \\
\text { optimum budget al. } \\
\text { ocation approaches } \\
\text { which could increase } \\
\text { overall performance of } \\
\text { the system more rapid } \\
\text { than the peanut butter } \\
\text { or potential weighted } \\
\text { approaches suggested in } \\
\text { the present article. The } \\
\text { dynamics behind the } \\
\text { time-varying distributions } \\
\text { of measurement and } \\
\text { inefficiency errors must } \\
\text { be taken into account } \\
\text { and a novel dynamic SFA } \\
\text { model must be developed } \\
\text { for capturing dynamics } \\
\text { accordingly }\end{array}$ \\
\hline $\begin{array}{l}\text { Ruiz and } \\
\text { Sirvent } \\
(2016)\end{array}$ & \begin{tabular}{|l|} 
Proposing a \\
DEA-based \\
benchmarking \\
method for \\
utilizing in case of \\
the lack of necessity \\
or unwillingness \\
for allowing for \\
individual DMU \\
situations
\end{tabular} & $\begin{array}{l}\text { Identifies a } \\
\text { specific frontier } \\
\text { of best practice } \\
\text { as the DEA- } \\
\text { effective frontier } \\
\text { dimension spanned } \\
\text { by technically } \\
\text { productive DMUs } \\
\text { within a shared } \\
\text { reference group }\end{array}$ & $\begin{array}{l}\text { Such a strategy } \\
\text { would be utilized } \\
\text { in case of the } \\
\text { lack of necessity } \\
\text { or unwillingness } \\
\text { for allowing } \\
\text { for individual } \\
\text { situations of } \\
\text { DMUs }\end{array}$ & $\begin{array}{l}\text { To examine a potential } \\
\text { extension of such a } \\
\text { traditional benchmarking } \\
\text { methodology to the case } \\
\text { wherein the DMUs could } \\
\text { be put in the groups with } \\
\text { the members experiencing } \\
\text { the same situations along } \\
\text { with research in (Cook \& } \\
\text { Zhu, 2007) }\end{array}$ \\
\hline $\begin{array}{l}\text { Mishra } \\
\text { and Pal } \\
\text { (2017) }\end{array}$ & $\begin{array}{l}\text { Their research } \\
\text { studied the } \\
\text { benchmark of the } \\
\text { Indian small and } \\
\text { medium enterprises } \\
\text { (SMEs) via DEA } \\
\text { for predicting } \\
\text { SMEs function for } \\
\text { effective decisions }\end{array}$ & $\begin{array}{l}\text { It assists managers } \\
\text { for predicting } \\
\text { functions of the } \\
\text { individual DMU } \\
\text { with regard to the } \\
\text { input used and } \\
\text { generating diverse } \\
\text { "what-if" scenarios }\end{array}$ & $\begin{array}{l}\text { Only done in } \\
\text { one region }\end{array}$ & $\begin{array}{l}\text { Can do it in other country } \\
\text { and compare with this } \\
\text { research result }\end{array}$ \\
\hline $\begin{array}{l}\text { (Wang, } \\
2017 \text { ) }\end{array}$ & $\begin{array}{l}\text { Techniques } \\
\text { and assessment } \\
\text { indicator of the } \\
\text { green building } \\
\text { benchmarks is } \\
\text { analyzed }\end{array}$ & $\begin{array}{l}\text { Analyzing validity } \\
\text { of the green } \\
\text { building project } \\
\text { that serve as a basis } \\
\text { of decision-taking } \\
\text { and consequently } \\
\text { sets out a course } \\
\text { of change for } \\
\text { technically invalid } \\
\text { or unsuccessful } \\
\text { project to scale }\end{array}$ & $\begin{array}{l}\text { Only done in } \\
\text { one industry }\end{array}$ & $\begin{array}{l}\text { Can do it in other domain } \\
\text { and compare with this } \\
\text { research result }\end{array}$ \\
\hline
\end{tabular}


Continue of Table 9

\begin{tabular}{|c|c|c|c|c|}
\hline Author & Main Idea & Advantage & Disadvantage & $\begin{array}{l}\text { Main suggestion } \\
\text { for future research }\end{array}$ \\
\hline $\begin{array}{l}\text { Zhou } \\
\text { et al. } \\
\text { (2019) }\end{array}$ & $\begin{array}{l}\text { A strategy has } \\
\text { been designed } \\
\text { to demonstrate } \\
\text { how DEA may be } \\
\text { applied with the } \\
\text { strategy of adapting } \\
\text { the benchmarking } \\
\text { to the goals to set } \\
\text { objectives as the } \\
\text { reference point } \\
\text { of incentive and } \\
\text { penalty plan }\end{array}$ & $\begin{array}{l}\text { Designing the } \\
\text { effective Reward } \\
\text { and Penalty } \\
\text { Mechanism (RPM) } \\
\text { for areas in the } \\
\text { basin with regard } \\
\text { to the function of } \\
\text { the Water Resource } \\
\text { Environmental } \\
\text { Carrying Capacity } \\
\text { (WRECC) }\end{array}$ & $\begin{array}{l}\text { Evaluation of } \\
\text { a novel DEA } \\
\text { benchmarking } \\
\text { model with } \\
\text { regard to the } \\
\text { assessment of } \\
\text { the performance } \\
\text { limit framework }\end{array}$ & $\begin{array}{l}\text { The proposed method } \\
\text { may be devised into a } \\
\text { more general framework, } \\
\text { in which a nonmonetary } \\
\text { compensation and } \\
\text { penalty plan would be } \\
\text { investigated }\end{array}$ \\
\hline $\begin{array}{l}\text { Samoi- } \\
\text { lenko } \\
\text { and } \\
\text { Osei- } \\
\text { Bryson } \\
(2019)\end{array}$ & $\begin{array}{l}\text { Presenting a novel } \\
\text { multimethod } \\
\text { benchmarking } \\
\text { method which } \\
\text { specifically } \\
\text { considers context } \\
\text { specific parameters } \\
\text { that impact } \\
\text { organizational } \\
\text { entities } \\
\text { performance }\end{array}$ & $\begin{array}{l}\text { It involves a new \& } \\
\text { creative integration } \\
\text { of multiple data } \\
\text { mining methods ( } \\
\text { Cluster analysis } \\
\text { (CA), decision tree } \\
\text { induction (DTI), } \\
\text { association rule } \\
\text { mining (ARM) with } \\
\text { DEA }\end{array}$ & $\begin{array}{l}\text { Not applicable } \\
\text { to static business } \\
\text { environments, } \\
\text { pro- duction } \\
\text { process that } \\
\text { is context- } \\
\text { independent } \\
\text { and process } \\
\text { improvement } \\
\text { approaches }\end{array}$ & $\begin{array}{l}\text { Future could be work } \\
\text { developed for the } \\
\text { mentioned area as } \\
\text { limitation }\end{array}$ \\
\hline $\begin{array}{l}\text { Nasraba- } \\
\text { di et al. } \\
(2019)\end{array}$ & $\begin{array}{l}\text { To suggest an } \\
\text { algorithm that } \\
\text { leads to a target } \\
\text { path for all } \\
\text { ineffective devices }\end{array}$ & $\begin{array}{l}\text { The proposed } \\
\text { model gives per } \\
\text { unit efficiency } \\
\text { scores. } \\
\text { Proposing an } \\
\text { algorithm that } \\
\text { results in an } \\
\text { inefficient target } \\
\text { path for each unit }\end{array}$ & $\begin{array}{l}\text { As a result, the } \\
\text { chosen path } \\
\text { would not } \\
\text { monotonically } \\
\text { converge to the } \\
\text { ultimate effective } \\
\text { target }\end{array}$ & $\begin{array}{l}\text { In this sort of layering } \\
\text { algorithms, any control } \\
\text { would not be made } \\
\text { over the amounts of } \\
\text { adjustment needed in } \\
\text { all steps. Nevertheless, } \\
\text { this concept proved to } \\
\text { be highly beneficial in } \\
\text { identifying target units in } \\
\text { the event of data on the } \\
\text { interval scale }\end{array}$ \\
\hline $\begin{array}{l}\text { Ashuri } \\
\text { et al. } \\
(2019)\end{array}$ & $\begin{array}{l}\text { DEA model, which } \\
\text { overcomes the } \\
\text { shortcomings of } \\
\text { current energy } \\
\text { benchmarking } \\
\text { building models }\end{array}$ & $\begin{array}{l}\text { Involves in } \\
\text { detection of low- } \\
\text { performance } \\
\text { buildings which } \\
\text { may be utilized as } \\
\text { the investment goals } \\
\text { to reduce building's } \\
\text { environmental } \\
\text { impacts }\end{array}$ & $\begin{array}{l}\text { As a result, } \\
\text { the chosen } \\
\text { path wouldn't } \\
\text { monotonically } \\
\text { converge to the } \\
\text { ultimate effective } \\
\text { targets }\end{array}$ & $\begin{array}{l}\text { It is recommended that } \\
\text { the high priority buildings } \\
\text { (specified with the use } \\
\text { of novel DEA model) } \\
\text { should be additionally } \\
\text { examined with the energy } \\
\text { simulation models to } \\
\text { plan the energy efficiency } \\
\text { retro-fitting }\end{array}$ \\
\hline
\end{tabular}


End of Table 9

\begin{tabular}{|c|c|c|c|c|}
\hline Author & Main Idea & Advantage & Disadvantage & $\begin{array}{l}\text { Main suggestion } \\
\text { for future research }\end{array}$ \\
\hline $\begin{array}{l}\text { Ruiz and } \\
\text { Sirvent } \\
(2020)\end{array}$ & $\begin{array}{l}\text { Develops DEA } \\
\text { benchmarking } \\
\text { models aimed at } \\
\text { defining suitable } \\
\text { objectives and } \\
\text { at defining } \\
\text { peers according } \\
\text { to appropriate } \\
\text { benchmark } \\
\text { selection criteria }\end{array}$ & $\begin{array}{l}\text { Through the } \\
\text { specification of } \\
\text { parameter } \alpha \text {, the } \\
\text { proposed models } \\
\text { will produce some } \\
\text { goals and peers, } \\
\text { which provide } \\
\text { numerous options } \\
\text { with the managers } \\
\text { for considering } \\
\text { in the future } \\
\text { planning as well } \\
\text { as performance } \\
\text { evaluation }\end{array}$ & $\begin{array}{l}\text { Cross-sectional } \\
\text { survey with } \\
\text { heterogeneous } \\
\text { members }\end{array}$ & $\begin{array}{l}\text { Potent lines of the future } \\
\text { work may involve, } \\
\text { expanding the models } \\
\text { suggested for addressing } \\
\text { the units, which would } \\
\text { be divided into classes } \\
\text { of similar circumstances } \\
\text { faced by members }\end{array}$ \\
\hline $\begin{array}{l}\text { Ramón } \\
\text { et al. } \\
(2020)\end{array}$ & $\begin{array}{l}\text { Identifying the } \\
\text { most reasonable } \\
\text { practices for } \\
\text { planning the } \\
\text { learning and } \\
\text { developing } \\
\text { improvements. } \\
\text { This study showed } \\
\text { how this core } \\
\text { concept could be } \\
\text { applied via cross- } \\
\text { benchmarking } \\
\text { concept that has } \\
\text { been considered as } \\
\text { one of the methods } \\
\text { formed into DEA } \\
\text { context }\end{array}$ & $\begin{array}{l}\text { Extending popular } \\
\text { benchmarking } \\
\text { method put } \\
\text { forward in Ruiz } \\
\text { and Sirvent (2016) } \\
\text { to a benchmarking } \\
\text { strategy for DMUs } \\
\text { against multiple } \\
\text { reference sets }\end{array}$ & $\begin{array}{l}\text { There's always a } \\
\text { major difference } \\
\text { between real } \\
\text { results and } \\
\text { targets in action }\end{array}$ & $\begin{array}{l}\text { Cross-benchmarking } \\
\text { needs to be generalized } \\
\text { to set more realistically } \\
\text { attainable goals }\end{array}$ \\
\hline
\end{tabular}

\section{Open issue and discussion}

This study has identified eight major applications including: transportation, service sector, product planning, maintenance, hotel industry, education and distribution and factors environment. They take up a total of $88 \%$ of all application-embedded papers. Among all the applications, the highest growth recently has been in transportation as well as other sectors. The transportation industry and the expansion of its production and service activities are among the issues that are of particular importance in the socio-economic aspects of societies, and any efforts to improve civic and the productivity of this industry has tremendous effects on the economic activity of other sectors. Transportation activities included in multiple way (sea, air and land), multi- ownership (public, private and cooperative), multidimensional (engineering, economic, political and environmental) multinational and regional (inland, provincial and national). The result of these activities is the creation of a spatial relationship between supply and demand with production and consumption centers, so that by shifting 
or transporting goods and passengers or transporting and moving people and goods from point to point, creates new value added. Therefore, the main issue of the research here is how it can be deployed for achieving highest level of efficacy in the transportation sector. For this purpose, DEA method could be used to measure the technical, managerial and rail-passenger transportation scale in fixed output conditions as well as variable returns relative to the scale of production in different parts during the years.

The transportation sector includes activities that have a strategic nature in the general process of the economy of the countries. Special attention is paid to domestic trade, foreign trade and tourism activities, so that any failure and crisis in the provision of service activities by it will reduce the economic well-being of the general population. Further, the statistics showed that the transportation sector is one of major consumers of petroleum products are among other sectors of the economy. Therefore, the introduction of alternative methods to save energy can have a significant effect in preventing the loss of energy. The multidimensional nature of public transportation and the different perspectives and its expression of performance have transformed the issue of transport performance assessment into a complex issue that involves many factors. A method for evaluating this problem is suitable to cover the various dimensions of the problem. The method of DEA has been carried out in recent years due to the flexibility and expansion of the equipment according to the conditions and coordination with the nature of the issue of transport performance assessment. Although studies in this field have contributed to the advancements in the aforementioned methods, it is still questionable to resolve the issues of transport assessment by a DEA method that can take different mode, aspects and perspectives simultaneously. In other hand, service activities due to their intangible nature, the provision of statistics from their performance are more complex and difficult. For this reason, economists call the service sector an undefined part of the economy.

In sectors like agricultural and industrial, the final product, due to its specific characteristics and the possibility of offering it on the market, easily reaches the consumer through the supply and demand system, and the sales process is easy and transparent. While none of these is true for the service. In the case of many services, the buyer or the consumer will be able to purchase the service without being able to get the right information from what it costs. Performance will be in full swing, but there will be more difficulties in creating competitive conditions in service markets. The lack of facilities for standardizing services and problems in this area, resulting in heterogeneous delivery of services, is one of the main issues limiting competition in the service sector. Quality aspects of service are so high that makes the definition and presentation of specific standards impossible. To overcome this issue there are two solutions. First, using productivity ratio or indicators where data gathering and information are available for all the time as long as organization continues its activity. This method is highly flexible and researchers could adopt any ratio to justify their organizations missions. The second technique is DEA. Comparing to the previous approach, it is providing better theoretical foundation. The total productivity of the production factors is calculated and estimated by the production factors and the Malmquist index, through its components, namely, technological efficiency, management efficiency and scale efficiency. This method from the set of DMUs introduces a number as efficient and, with the help of 
them, forms the efficiency boundary. Then, this boundary becomes the criterion for assessing other units. Therefore, the criteria for assessing the decision-making units are in the same situation. Another important feature of this analysis is the combination of a set of factors and therefore it evaluates all the input and output factors together. Another feature is being offset of its models. In other word, this feature allows each decision maker to cover and compensate their deficits or weaknesses in any output or input with the help of other outputs or inputs. Given that DEA models are solved by linear programming, the linear programming method is not sensitive to the measurement unit, and therefore inputs and outputs can be used from different measurement units. Even though there are some limitations, but it is still acceptable and desirable technique to measure the efficiency of the organization in different sectors.

In Table 10, some of the factors investigated in the reviewed articles. By being practical it means show functional the articles are. By used articles diversity the abundance of the articles prospected which have been used at each item. Efficiency and productivity items have investigated each article's effectiveness and output. The remained two items refer to the inventiveness and self-efficacy of each article. Studies show that in the transport sector, the being practical index is more important and less one belongs to self-efficacy. Also, in the service sector and maintenance being the practical and efficiency index obtained as more important and less important belongs to self-efficacy. In the distribution section, being the practical index, productivity and efficiency are more important and the personal innovation index took less important. Efficiency took first place in the hotel industry and being practical and productivity placed in the last. In product planning, the indicators of being practical and efficiency are of relative importance. While in education section the area of being practical is more important than other sections. In other sections all have relative importance, while the self-efficacy is of low importance. Finally, among the environmental factors, the efficiency section obtained more importance, and self-efficacy got lower place.

Table 10. The summarized of previous literature

\begin{tabular}{|c|c|c|c|c|c|c|}
\hline Author & $\begin{array}{c}\text { Being } \\
\text { Practical }\end{array}$ & $\begin{array}{l}\text { Articles } \\
\text { Diversity }\end{array}$ & $\begin{array}{l}\text { Effi- } \\
\text { ciency }\end{array}$ & $\begin{array}{l}\text { Produc- } \\
\text { tivity }\end{array}$ & $\begin{array}{c}\text { Personal } \\
\text { Innovation }\end{array}$ & Self-Efficacy \\
\hline \multicolumn{7}{|c|}{ Transportation } \\
\hline Yoshida and Fujimoto (2004) & $x$ & $\times$ & $\checkmark$ & $\times$ & $x$ & $x$ \\
\hline Martín and Román (2006) & $x$ & $\checkmark$ & $\checkmark$ & $x$ & $\checkmark$ & $x$ \\
\hline Quaresma Dias et al. (2009) & $\checkmark$ & $\checkmark$ & $\times$ & $x$ & $x$ & $x$ \\
\hline De Koster et al. (2009) & $\checkmark$ & $\times$ & $\times$ & $\checkmark$ & $x$ & $x$ \\
\hline Jie Wu et al. (2010) & $x$ & $x$ & $\checkmark$ & $x$ & $\checkmark$ & $x$ \\
\hline Lim et al. (2011) & $\checkmark$ & $x$ & $\checkmark$ & $x$ & $x$ & $x$ \\
\hline Park et al. (2012) & $\checkmark$ & $\checkmark$ & $x$ & $x$ & $x$ & $x$ \\
\hline Egilmez and McAvoy (2013) & $\checkmark$ & $x$ & $\times$ & $\checkmark$ & $\checkmark$ & $x$ \\
\hline Sharma et al. (2016) & $x$ & $\times$ & $\checkmark$ & $x$ & $x$ & $x$ \\
\hline Park and Sung (2016) & $\checkmark$ & $x$ & $\checkmark$ & $x$ & $x$ & $x$ \\
\hline Melo et al. (2018) & $\checkmark$ & $x$ & $\checkmark$ & $\checkmark$ & $x$ & $x$ \\
\hline
\end{tabular}


Continue of Table 10

\begin{tabular}{|c|c|c|c|c|c|c|}
\hline Author & $\begin{array}{c}\text { Being } \\
\text { Practical }\end{array}$ & $\begin{array}{l}\text { Articles } \\
\text { Diversity }\end{array}$ & $\begin{array}{l}\text { Effi- } \\
\text { ciency }\end{array}$ & $\begin{array}{l}\text { Produc- } \\
\text { tivity }\end{array}$ & $\begin{array}{l}\text { Personal } \\
\text { Innovation }\end{array}$ & Self-Efficacy \\
\hline \multicolumn{7}{|c|}{ Service } \\
\hline Sherman and Zhu (2006) & $\times$ & $\checkmark$ & $\times$ & $x$ & $\checkmark$ & $x$ \\
\hline Deville (2009) & $\checkmark$ & $x$ & $x$ & $x$ & $\checkmark$ & $x$ \\
\hline Baek and Lee (2009) & $x$ & $x$ & $\checkmark$ & $x$ & $x$ & $x$ \\
\hline Kumar and Vincent (2011) & $x$ & $\checkmark$ & $\checkmark$ & $\checkmark$ & $x$ & $x$ \\
\hline Lai et al. (2011) & $\checkmark$ & $x$ & $x$ & $x$ & $x$ & $x$ \\
\hline Sufian (2011a) & $x$ & $x$ & $\checkmark$ & $x$ & $x$ & $x$ \\
\hline $\mathrm{Wu}(2012)$ & $\checkmark$ & $x$ & $x$ & $x$ & $\checkmark$ & $x$ \\
\hline Nigam et al. (2012) & $\checkmark$ & $\checkmark$ & $\sqrt{ }$ & $x$ & $\checkmark$ & $x$ \\
\hline $\begin{array}{l}\text { Karbassi Yazdi and Abdi } \\
\text { (2017) }\end{array}$ & $x$ & $\checkmark$ & $\checkmark$ & $x$ & $x$ & $x$ \\
\hline $\begin{array}{l}\text { Álvarez-Rodríguez et al. } \\
\text { (2019) }\end{array}$ & $\checkmark$ & $\times$ & $x$ & $x$ & $x$ & $x$ \\
\hline \multicolumn{7}{|c|}{ Maintenance } \\
\hline Gouveia et al. (2015) & $\checkmark$ & $\times$ & $\checkmark$ & $\times$ & $x$ & $x$ \\
\hline Assaf et al. (2015) & $\checkmark$ & $x$ & $x$ & $\checkmark$ & $x$ & $x$ \\
\hline \multicolumn{7}{|c|}{ Distribution } \\
\hline Jha et al. (2008) & $\times$ & $\times$ & $\checkmark$ & $\times$ & $x$ & $x$ \\
\hline Ajodhia (2010) & $\checkmark$ & $x$ & $x$ & $\checkmark$ & $x$ & $\checkmark$ \\
\hline Hung Lau (2012) & $\checkmark$ & $x$ & $\checkmark$ & $\checkmark$ & $x$ & $x$ \\
\hline \multicolumn{7}{|c|}{ Hotel Industry } \\
\hline Assaf (2012) & $\times$ & $\times$ & $\checkmark$ & $\times$ & $\checkmark$ & $x$ \\
\hline Wu et al. (2013) & $x$ & $\checkmark$ & $\checkmark$ & $x$ & $x$ & $x$ \\
\hline \multicolumn{7}{|c|}{ Product Planning } \\
\hline Braglia et al. (2003) & $\checkmark$ & $\times$ & $\checkmark$ & $\times$ & $x$ & $\times$ \\
\hline Trappey and Chiang (2008) & $x$ & $x$ & $\checkmark$ & $x$ & $x$ & $x$ \\
\hline Shabanpour et al. (2017) & $\checkmark$ & $\checkmark$ & $x$ & $x$ & $x$ & $x$ \\
\hline \multicolumn{7}{|c|}{ Education } \\
\hline $\begin{array}{l}\text { Reichmann and } \\
\text { Sommersguter-Reichmann } \\
\text { (2006) }\end{array}$ & $x$ & $\checkmark$ & $\checkmark$ & $\checkmark$ & $x$ & $x$ \\
\hline $\begin{array}{l}\text { Gourishankar and Sai } \\
\text { Lokachari (2012) }\end{array}$ & $\checkmark$ & $x$ & $\times$ & $\checkmark$ & $x$ & $\times$ \\
\hline Cook et al. (2017) & $\checkmark$ & $\times$ & $\times$ & $\times$ & $\checkmark$ & $\times$ \\
\hline Ramón et al. (2018) & $\checkmark$ & $x$ & $\checkmark$ & $x$ & $x$ & $x$ \\
\hline \multicolumn{7}{|c|}{ Environment } \\
\hline Liu et al. (2019) & $\times$ & $\times$ & $\checkmark$ & $\times$ & $\checkmark$ & $\times$ \\
\hline Didehkhani et al. (2019) & $\checkmark$ & $x$ & $\checkmark$ & $x$ & $x$ & $x$ \\
\hline Das \& Kundu (2019) & $\checkmark$ & $x$ & $\checkmark$ & $\checkmark$ & $x$ & $x$ \\
\hline
\end{tabular}


End of Table 10

\begin{tabular}{|c|c|c|c|c|c|c|}
\hline Author & $\begin{array}{l}\text { Being } \\
\text { Practical }\end{array}$ & $\begin{array}{l}\text { Articles } \\
\text { Diversity }\end{array}$ & $\begin{array}{l}\text { Effi- } \\
\text { ciency }\end{array}$ & $\begin{array}{l}\text { Produc- } \\
\text { tivity }\end{array}$ & $\begin{array}{l}\text { Personal } \\
\text { Innovation }\end{array}$ & Self-Efficacy \\
\hline \multicolumn{7}{|c|}{ Other Topics } \\
\hline Díaz et al. (2004) & $x$ & $\checkmark$ & $x$ & $x$ & $x$ & $x$ \\
\hline Wu et al. (2013) & $\checkmark$ & $x$ & $\sqrt{ }$ & $x$ & $\checkmark$ & $x$ \\
\hline Oh and Shin (2015) & $\checkmark$ & $x$ & $x$ & $x$ & $\checkmark$ & $x$ \\
\hline Ruiz and Sirvent (2016) & $\checkmark$ & $x$ & $x$ & $\checkmark$ & $x$ & $x$ \\
\hline Mishra and Pal (2017) & $x$ & $\checkmark$ & $\checkmark$ & $x$ & $x$ & $x$ \\
\hline Wang (2017) & $\checkmark$ & $x$ & $x$ & $x$ & $\checkmark$ & $x$ \\
\hline Zhou et al. (2019) & $\checkmark$ & $x$ & $x$ & $x$ & $x$ & $x$ \\
\hline $\begin{array}{l}\text { Samoilenko and Osei-Bryson } \\
\text { (2019) }\end{array}$ & $x$ & $\times$ & $\checkmark$ & $\times$ & $\checkmark$ & $x$ \\
\hline Nasrabadi et al. (2019) & $x$ & $x$ & $x$ & $x$ & $\checkmark$ & $x$ \\
\hline Ashuri et al. (2019) & $\checkmark$ & $x$ & $x$ & $\checkmark$ & $\checkmark$ & $\checkmark$ \\
\hline Ruiz and Sirvent (2020) & $\checkmark$ & $x$ & $x$ & $x$ & $x$ & $x$ \\
\hline Ramón et al. (2020) & $x$ & $x$ & $\checkmark$ & $x$ & $x$ & $x$ \\
\hline
\end{tabular}

\section{Conclusions}

In companies, managers use benchmarking tools to evaluate their processes and compare them with best practices in a similar group in an industry. By measuring the effectiveness of measures, identification of the most successful companies leads to the setting of goals and enables these organizations to be able to improve their performance by learning from others. Companies' rating based on assessments that offer beneficial data to decide. In general, the higher-rank refers to the more acceptable performances. The literature of applications of DEA methods in benchmarking Systematically reviewed. The DEA model is a useful and efficient tool for evaluating DMU activities. Identifying weak functions based on general information about activities is a main benefit of the DEA utilization in benchmarking. Since access to this information is often easy and cost-effective, the cost of DEA is often low. In addition, because the DEA model can be implemented based on non-financial valuations, it is also appropriate to compare DMUs with different financial conditions. However, since the evaluation of the DMU is attributable to virtual DMUs, the relationship between the results is due to the appropriateness of the assumed criteria and available information. Finally, results showed that DEA model cannot provide sufficient advice on the improvement of conditions, based on general information, but can only identify the potential of DMUs for improving conditions and facilitate decision making on how to analyze activities. Hence, the DEA model should be considered as an additional tool in activity-based management.

Hence, in this paper, the past articles of DEA in benchmarking systematically surveyed. 51 selected papers classified in eight classes that 11 of them are about transportation, 10 about service sector, education 4 , and 13 of them are about factor of environment, product planning, hotel industry, distribution, maintenance and 12 of them about other sectors. These 
articles reviewed and compared, and the results were collected. The results have shown that most of the papers tried to improves transportation process. The present paper has some restrictions. One issue is only exploring in popular Search Engine. There might be other scientific magazines offering a better illustration of the pertinent investigations. In addition, the papers excluded written in languages other than English. But, there might be many other related papers written in other languages. Lastly, researchers can perform more studies using other tools like interviews.

\section{Acknowledgements}

We wish to express our gratitude to the anonymous reviewers and Editor in Chief, Prof. Zavadskas, for their insightful and constructive comments. Also, the authors would like to deeply thank The Deputy of Research \& Technology of Islamic Azad University of Urmia for their generous supports.

\section{Author contributions}

Omid Akbarian wrote the first draft of the article with supervisory of the Reza Rostamzadeh. Reza Rostamzadeh and Audrius Banaitis provided extensive advice throughout the study regarding the abstract, introduction, literature review, research methodology, data analysis, results and discussion, and conclusions of the manuscript. The discussion was a team task. Omid Akbarian and Zeyanb Soltani conducted data analysis. All authors have read and approved the final manuscript.

\section{References}

Adler, N., Liebert, V., \& Yazhemsky, E. (2013). Benchmarking airports from a managerial perspective. Omega, 41(2), 442-458. http://doi.org/10.1016/j.omega.2012.02.004

Aires, R. F. de. F., Salgado, C. C. R., \& Ayres, K. V. (2014). The PDCA cycle in practice: The experience of managing subjects of the administration course of the Federal University of Paraíba-UFPBCampus I. International Journal of Advanced Operations Management, 6(4), 324-334. https://doi.org/10.1504/IJAOM.2014.066826

Ajodhia, V. (2010). Integrated cost and quality benchmarking for electricity distribution using DEA. International Journal of Energy Sector Management, 4(3), 417-433. https://doi.org/10.1108/17506221011073888

Alosani, M. S., Al-Dhaafri, H. S., \& Yusoff, R. Z. B. (2016). Mechanism of benchmarking and its impact on organizational performance. International Journal of Business and Management, 11(10), 172. https://doi.org/10.5539/ijbm.v11n10p172

Álvarez-Rodríguez, C., Martín-Gamboa, M., \& Iribarren, D. (2019). Combined use of data envelopment analysis and life cycle assessment for operational and environmental benchmarking in the service sector: A case study of grocery stores. Science of The Total Environment, 667, 799-808. https://doi.org/10.1016/j.scitotenv.2019.02.433

Anand, G., \& Kodali, R. (2008). Benchmarking the benchmarking models. Benchmarking: An International Journal, 15(3), 257-291. https://doi.org/10.1108/14635770810876593

Asher, M., \& Kanji, G. K. (1996). 100 methods for total quality management. Sage Publications. 
Ashuri, B., Wang, J., Shahandashti, M., \& Baek, M. (2019). A data envelopment analysis (DEA) model for building energy benchmarking. Journal of Engineering, Design and Technology, 17(4), 747-768. https://doi.org/10.1108/JEDT-08-2018-0127

Assaf, A. G. (2012). Benchmarking the Asia Pacific tourism industry: A Bayesian combination of DEA and stochastic frontier. Tourism Management, 33(5), 1122-1127.

https://doi.org/10.1016/j.tourman.2011.11.021

Assaf, S. A., Hadidi, L. A., Hassanain, M. A., \& Rezq, M. F. (2015). Performance evaluation and benchmarking for maintenance decision making units at petrochemical corporation using a DEA model. The International Journal of Advanced Manufacturing Technology, 76(9-12), 1957-1967. https://doi.org/10.1007/s00170-014-6422-2

Azadeh, A., Ghaderi, S., \& Izadbakhsh, H. (2008). Integration of DEA and AHP with computer simulation for railway system improvement and optimization. Applied Mathematics and Computation, 195(2), 775-785. https://doi.org/10.1016/j.amc.2007.05.023

Baek, C., \& Lee, J.-d. (2009). The relevance of DEA benchmarking information and the Least-Distance Measure. Mathematical and Computer Modelling, 49(1-2), 265-275. https://doi.org/10.1016/j.mcm.2008.08.007

Barber, E. (2004). Benchmarking the management of projects: A review of current thinking. International Journal of Project Management, 22(4), 301-307. https://doi.org/10.1016/j.ijproman.2003.08.001

Belton, V., \& Vickers, S. P. (1993). Demystifying DEA - a visual interactive approach based on multiple criteria analysis. Journal of the Operational research Society, 44(9), 883-896. https://doi.org/10.1057/jors.1993.157

Bogan, C. E., \& English, M. J. (1994). Benchmarking for best practices: Winning through innovative adaptation. McGraw-Hill.

Boxwell Jr, R. J. (1994). Benchmarking for competitive advantage. McGraw-Hill.

Braglia, M., Zanoni, S., \& Zavanella, L. (2003). Measuring and benchmarking productive systems performances using DEA: An industrial case. Production Planning \& Control, 14(6), 542-554. https://doi.org/10.1080/09537280310001621994

Brah, S. A., Lin Ong, A., \& Madhu Rao, B. (2000). Understanding the benchmarking process in Singapore. International Journal of Quality \& Reliability Management, 17(3), 259-275. https://doi.org/10.1108/02656710010306157

Camp, R. C. (1989). Benchmarking: The search for industry best practices that lead to superior performance. ASQ Quality Press.

Charnes, A., Cooper, W. W., \& Rhodes, E. (1978). Measuring the efficiency of decision making units. European Journal of Operational Research, 2(6), 429-444. https://doi.org/10.1016/0377-2217(78)90138-8

Chen, H.-L. (2002). Benchmarking and quality improvement: A quality benchmarking deployment approach. International Journal of Quality \& Reliability Management, 19(6), 757-773. https://doi.org/10.1108/02656710210429609

Chiu, S.-H., \& Lin, T.-Y. (2018). Performance evaluation of taiwanese international tourist hotels: Evidence from a modified NDEA model with ICA technique. Technological and Economic Development of Economy, 24(4), 1560-1580. https://doi.org/10.3846/tede.2018.3116

Chodakowska, E., \& Nazarko, J. (2017). Environmental DEA method for assessing productivity of European countries. Technological and Economic Development of Economy, 23(4), 589-607. https://doi.org/10.3846/20294913.2016.1272069

Cook, W. D., Ruiz, J. L., Sirvent, I., \& Zhu, J. (2017). Within-group common benchmarking using DEA. European Journal of Operational Research, 256(3), 901-910. https://doi.org/10.1016/j.ejor.2016.06.074 
Cook, W. D., Seiford, L. M., \& Zhu, J. (2004). Models for performance benchmarking: Measuring the effect of e-business activities on banking performance. Omega, 32(4), 313-322. https://doi.org/10.1016/j.omega.2004.01.001

Cook, W. D., \& Zhu, J. (2007). Within-group common weights in DEA: An analysis of power plant efficiency. European Journal of Operational Research, 178(1), 207-216. https://doi.org/10.1016/j.ejor.2006.01.019

Das, S., \& Kundu, A. (2019). Benchmarking a country for efficiency improvement: A DEA-based approach. Journal of Global Entrepreneurship Research, 9(1), 49. https://doi.org/10.1186/s40497-019-0173-3

De Koster, M., Balk, B., \& van Nus, W. (2009). On using DEA for benchmarking container terminals. International Journal of Operations \& Production Management, 29(11), 1140-1155. https://doi.org/10.1108/01443570911000168

Deville, A. (2009). Branch banking network assessment using DEA: A benchmarking analysis - a note. Management Accounting Research, 20(4), 252-261. https://doi.org/10.1016/j.mar.2009.08.001

Díaz, J. R., Poyato, E. C., \& Luque, R. L. (2004). Applying benchmarking and data envelopment analysis (DEA) techniques to irrigation districts in Spain. Irrigation and Drainage: The Journal of the International Commission on Irrigation and Drainage, 53(2), 135-143. https://doi.org/10.1002/ird.128

Didehkhani, H., Lotfi, F. H., \& Sadi-Nezhad, S. (2019). Practical benchmarking in DEA using artificial DMUs. Journal of Industrial Engineering International, 15(2), 293-301. https://doi.org/10.1007/s40092-018-0281-7

Donthu, N., Hershberger, E. K., \& Osmonbekov, T. (2005). Benchmarking marketing productivity using data envelopment analysis. Journal of Business Research, 58(11), 1474-1482. https://doi.org/10.1016/j.jbusres.2004.05.007

Doyle, J., \& Green, R. (1993). Data envelopment analysis and multiple criteria decision making. Omega, 21(6), 713-715. https://doi.org/10.1016/0305-0483(93)90013-B

Egilmez, G., \& McAvoy, D. (2013). Benchmarking road safety of us states: A DEA-based Malmquist productivity index approach. Accident Analysis \& Prevention, 53, 55-64. https://doi.org/10.1016/j.aap.2012.12.038

Elmuti, D., \& Kathawala, Y. (1997). An overview of benchmarking process: A tool for continuous improvement and competitive advantage. Benchmarking for Quality Management \& Technology, 4(4), 229-243. https://doi.org/10.1108/14635779710195087

Emrouznejad, A., \& Yang, G.-l. (2018). A survey and analysis of the first 40 years of scholarly literature in DEA: 1978-2016. Socio-Economic Planning Sciences, 61, 4-8. https://doi.org/10.1016/j.seps.2017.01.008

Farrell, M. J. (1957). The measurement of productive efficiency. Journal of the Royal Statistical Society. Series A (General), 120(3), 253-290. https://doi.org/10.2307/2343100

Fernandez, P., McCarthy, I. P., \& Rakotobe-Joel, T. (2001). An evolutionary approach to benchmarking. Benchmarking: An International Journal, 8(4), 281-305. https://doi.org/10.1108/14635770110403783

Gourishankar, V., \& Sai Lokachari, P. (2012). Benchmarking educational development efficiencies of the Indian states: A DEA approach. International Journal of Educational Management, 26(1), 99-130. https://doi.org/10.1108/09513541211194400

Gouveia, M., Dias, L., Antunes, C., Boucinha, J., \& Inácio, C. (2015). Benchmarking of maintenance and outage repair in an electricity distribution company using the value-based DEA method. Omega, 53, 104-114. https://doi.org/10.1016/j.omega.2014.12.003

Heib, R., \& Daneva, M. (1995). Benchmarks and benchmarking: A definitional analysis. Institute for Information System, University of Saarlandes.

Hong, S.-M., Paterson, G., Mumovic, D., \& Steadman, P. (2014). Improved benchmarking comparability for energy consumption in schools. Building Research \& Information, 42(1), 47-61.

https://doi.org/10.1080/09613218.2013.814746 
Horta, I. M., Kapelko, M., Oude Lansink, A., \& Camanho, A. S. (2016). The impact of internationalization and diversification on construction industry performance. International Journal of Strategic Property Management, 20(2), 172-183. https://doi.org/10.3846/1648715X.2015.1123201

Hung Lau, K. (2012). Distribution network rationalisation through benchmarking with DEA. Benchmarking: An International Journal, 19(6), 668-689. https://doi.org/10.1108/14635771211284260

Jha, D. K., Yorino, N., \& Zoka, Y. (2008). Benchmarking of generation and distribution units in Nepal using modified DEA models. IEEJ Transactions on Power and Energy, 128(9), 1082-1090. https://doi.org/10.1541/ieejpes.128.1082

Kaganova, O., \& Telgarsky, J. (2018). Management of capital assets by local governments: An assessment and benchmarking survey. International Journal of Strategic Property Management, 22(2), 143-156. https://doi.org/10.3846/ijspm.2018.445

Karbassi Yazdi, A., \& Abdi, F. (2017). Designing robust model for banks benchmarking based on Rembrandt method and DEA. Benchmarking: An International Journal, 24(2), 431-444. https://doi.org/10.1108/BIJ-01-2015-0001

Kılkış, Ş. (2015). Composite index for benchmarking local energy systems of Mediterranean port cities. Energy, 92, 622-638. https://doi.org/10.1016/j.energy.2015.06.093

Kumar, A., Antony, J., \& Dhakar, T. S. (2006). Integrating quality function deployment and benchmarking to achieve greater profitability. Benchmarking: An International Journal, 13(3), 290-310. https://doi.org/10.1108/14635770610668794

Kumar, M., \& Vincent, C. (2011). Benchmarking Indian banks using DEA in post-reform period: A progressive time-weighted mean approach. The Service Industries Journal, 31(14), 2455-2485. https://doi.org/10.1080/02642069.2010.504818

Lai, M.-C., Huang, H.-C., \& Wang, W.-K. (2011). Designing a knowledge-based system for benchmarking: A DEA approach. Knowledge-Based Systems, 24(5), 662-671.

https://doi.org/10.1016/j.knosys.2011.02.006

Li, L., Su, Q., \& Chen, X. (2011). Ensuring supply chain quality performance through applying the scor model. International Journal of Production Research, 49(1), 33-57. https://doi.org/10.1080/00207543.2010.508934

Lim, S., Bae, H., \& Lee, L. H. (2011). A study on the selection of benchmarking paths in DEA. Expert Systems with Applications, 38(6), 7665-7673. https://doi.org/10.1016/j.eswa.2010.12.148

Liu, X., Zhu, Q., Chu, J., Ji, X., \& Li, X. (2019). Environmental performance and benchmarking information for coal-fired power plants in China: A DEA approach. Computational Economics, 54(4), 1287-1302. https://doi.org/10.1007/s10614-015-9560-1

Makui, A., Alinezhad, A., Kiani Mavi, R., \& Zohrehbandian, M. (2008). A goal programming method for finding common weights in DEA with an improved discriminating power for efficiency. Journal of Industrial and Systems Engineering, 1(4), 293-303.

Mardani, A., Zavadskas, E. K., Streimikiene, D., Jusoh, A., \& Khoshnoudi, M. (2017). A comprehensive review of data envelopment analysis (DEA) approach in energy efficiency. Renewable and Sustainable Energy Reviews, 70, 1298-1322. https://doi.org/10.1016/j.rser.2016.12.030

Martín, J. C., \& Román, C. (2006). A benchmarking analysis of Spanish commercial airports. A comparison between SMOP and DEA ranking methods. Networks and Spatial Economics, 6(2), 111-134. https://doi.org/10.1007/s11067-006-7696-1

Melo, I. C., Junior, P. N. A., Perico, A. E., Guzman, M. G. S., \& Rebelatto, D. A. d. N. (2018). Benchmarking freight transportation corridors and routes with data envelopment analysis (DEA). Benchmarking: An International Journal, 25(2), 713-742. https://doi.org/10.1108/BIJ-11-2016-0175

Min, H., \& Jong Joo, S. (2006). Benchmarking the operational efficiency of third party logistics providers using data envelopment analysis. Supply Chain Management: An International Journal, 11(3), 259-265. https://doi.org/10.1108/13598540610662167 
Mishra, R. K., \& Pal, S. (2017). Benchmarking Indian SMEs: A DEA approach. International Journal of Process Management and Benchmarking, 7(3), 305-331. https://doi.org/10.1504/IJPMB.2017.084907

Mollaee, N., \& Rahimi, R. (2009). New method for effective benchmarking in health, safety \& environment management. Paper presented at the Proceeding Book of the Environment 2009 Seminar, Abu Dhabi.

Nasrabadi, N., Dehnokhalaji, A., Korhonen, P., \& Wallenius, J. (2019). A stepwise benchmarking approach to DEA with interval scale data. Journal of the Operational Research Society, 70(6), 954-961. https://doi.org/10.1080/01605682.2018.1471375

Nazarko, J., \& Chodakowska, E. (2017). Labour efficiency in construction industry in Europe based on frontier methods: Data envelopment analysis and stochastic frontier analysis. Journal of Civil Engineering and Management, 23(6), 787-795. https://doi.org/10.3846/13923730.2017.1321577

Nigam, V., Thakur, T., Sethi, V., \& Singh, R. (2012). Benchmarking of Indian mobile telecom operators using DEA with sensitivity analysis. Benchmarking: An International Journal, 19(2), 219-238. https://doi.org/10.1108/14635771211224545

Oh, S.-C., \& Shin, J. (2015). The impact of mismeasurement in performance benchmarking: A Monte Carlo comparison of SFA and DEA with different multi-period budgeting strategies. European Journal of Operational Research, 240(2), 518-527. https://doi.org/10.1016/j.ejor.2014.07.026

Papagapiou, A., Mingers, J., \& Thanassoulis, E. (1997). Would you buy a used car with DEA? OR Insight, 10(1), 13-19. https://doi.org/10.1057/ori.1997.3

Park, J., Lim, S., \& Bae, H. (2012). DEA-based port efficiency improvement and stepwise benchmarking target selection. Information: An International Interdisciplinary Journal, 15, 6155-6172.

Park, J., \& Sung, S.-I. (2016). Integrated approach to construction of benchmarking network in DEAbased stepwise benchmark target selection. Sustainability, 8(7), 600. https://doi.org/10.3390/su8070600

Peng Wong, W., \& Yew Wong, K. (2008). A review on benchmarking of supply chain performance measures. Benchmarking: An international Journal, 15(1), 25-51. https://doi.org/10.1108/14635770810854335

Pickrell, S., Garnett, N., \& Baldwin, J. (1997). Measuring up: A practical guide to benchmarking in construction. Construction Research Communications Watford.

Portela, M. C. A. S., Camanho, A. S., Almeida, D. Q., Lopes, L., Silva, S. N., \& Castro, R. (2016). Benchmarking hospitals through a web based platform. Benchmarking: An International Journal, 23(3), 722-739. https://doi.org/10.1108/BIJ-07-2014-0067

Quaresma Dias, J. C., Garrido Azevedo, S., Ferreira, J., \& Palma, S. F. (2009). A comparative benchmarking analysis of main Iberian container terminals: A DEA approach. International Journal of Shipping and Transport Logistics, 1(3), 260-275. https://doi.org/10.1504/IJSTL.2009.027534

Radojicic, M., Savic, G., \& Jeremic, V. (2018). Measuring the efficiency of banks: The bootstrapped i-distance GAR DEA approach. Technological and Economic Development of Economy, 24(4), 1581-1605. https://doi.org/10.3846/tede.2018.3699

Ramón, N., Ruiz, J. L., \& Sirvent, I. (2018). Two-step benchmarking: Setting more realistically achievable targets in DEA. Expert Systems with Applications, 92, 124-131. https://doi.org/10.1016/j.eswa.2017.09.044

Ramón, N., Ruiz, J. L., \& Sirvent, I. (2020). Cross-benchmarking for performance evaluation: Looking across best practices of different peer groups using DEA. Omega, 92, 102169. https://doi.org/10.1016/j.omega.2019.102169

Reichmann, G., \& Sommersguter-Reichmann, M. (2006). University library benchmarking: An international comparison using DEA. International Journal of Production Economics, 100(1), 131-147. https://doi.org/10.1016/j.ijpe.2004.10.007 
Ruiz, J. L., \& Sirvent, I. (2016). Common benchmarking and ranking of units with DEA. Omega, 65, 1-9. https://doi.org/10.1016/j.omega.2015.11.007

Ruiz, J. L., \& Sirvent, I. (2020). Benchmarking within a DEA framework: Setting the closest targets and identifying peer groups with the most similar performances. International Transactions in Operational Research. https://doi.org/10.1111/itor.12779

Samoilenko, S., \& Osei-Bryson, K.-M. (2019). A data analytic benchmarking methodology for discovering common causal structures that describe context-diverse heterogeneous groups. Expert Systems with Applications, 117, 330-344. https://doi.org/10.1016/j.eswa.2018.09.054

Sarkis, J. (2001). Benchmarking for agility. Benchmarking: An International Journal, 8(2), 88-107. https://doi.org/10.1108/14635770110389816

Sellitto, M. A., Pereira, G. M., Borchardt, M., Da Silva, R. I., \& Viegas, C. V. (2015). A scor-based model for supply chain performance measurement: Application in the footwear industry. International Journal of Production Research, 53(16), 4917-4926. https://doi.org/10.1080/00207543.2015.1005251

Seol, H., Choi, J., Park, G., \& Park, Y. (2007). A framework for benchmarking service process using data envelopment analysis and decision tree. Expert Systems with Applications, 32(2), 432-440. https://doi.org/10.1016/j.eswa.2005.12.012

Shabanpour, H., Yousefi, S., \& Saen, R. F. (2017). Future planning for benchmarking and ranking sustainable suppliers using goal programming and robust double frontiers DEA. Transportation Research Part D: Transport and Environment, 50, 129-143. https://doi.org/10.1016/j.trd.2016.10.022

Sharma, M. G., Debnath, R. M., Oloruntoba, R., \& Sharma, S. M. (2016). Benchmarking of rail transport service performance through DEA for Indian railways. The International Journal of Logistics Management.

Sherman, H. D., \& Zhu, J. (2006). Benchmarking with quality-adjusted DEA (Q-DEA) to seek lowercost high-quality service: Evidence from a U.S. bank application. Annals of Operations Research, 145(1), 301-319. https://doi.org/10.1007/s10479-006-0037-4

Silva, A. S., Medeiros, C. F., \& Vieira, R. K. (2017). Cleaner production and PDCA cycle: Practical application for reducing the Cans Loss Index in a beverage company. Journal of Cleaner Production, 150, 324-338. https://doi.org/10.1016/j.jclepro.2017.03.033

Soheilirad, S., Govindan, K., Mardani, A., Zavadskas, E. K., Nilashi, M., \& Zakuan, N. (2018). Application of data envelopment analysis models in supply chain management: A systematic review and meta-analysis. Annals of Operations Research, 271(2), 915-969.

https://doi.org/10.1007/s10479-017-2605-1

Stewart, T. J. (1994). Data envelopment analysis and multiple criteria decision making: A response. Omega, 22(2), 205-206. https://doi.org/10.1016/0305-0483(94)90079-5

Stewart, T. J. (1996). Relationships between data envelopment analysis and multicriteria decision analysis. Journal of the Operational Research Society, 47(5), 654c665. https://doi.org/10.1057/jors.1996.77

Sufian, F. (2011a). Benchmarking the efficiency of the Korean banking sector: A DEA approach. Benchmarking: An International Journal, 18(1), 107-127. https://doi.org/10.1108/14635771111109841

Swanson, D. (2016). Transportation price benchmarking: Implications for firm performance. Benchmarking: An International Journal, 23(4), 1015-1026. https://doi.org/10.1108/BIJ-04-2015-0034

Trappey, A. J., \& Chiang, T.-A. (2008). A DEA benchmarking methodology for project planning and management of new product development under decentralized profit-center business model. Advanced Engineering Informatics, 22(4), 438-444. https://doi.org/10.1016/j.aei.2008.06.003

Van Eck, N. J., \& Waltman, L. (2014). Visualizing bibliometric networks. In Measuring scholarly impact (pp. 285-320). Springer. https://doi.org/10.1007/978-3-319-10377-8_13

Wang, Y.-G. (2017). Benchmarking establishment for green building based on DEA and individual advantage identification. Journal of Interdisciplinary Mathematics, 20(6-7), 1459-1463.

https://doi.org/10.1080/09720502.2017.1382157 
Wong, W. P., \& Wong, K. Y. (2008). A review on benchmarking of supply chain performance measures. Benchmarking, 15(1), 25-51. https://doi.org/10.1108/14635770810854335

Wu, H., Chen, B., Xia, Q., \& Zhou, H. (2013). Ranking and benchmarking of the Asian games achievements based on DEA: The case of Guangzhou 2010. Asia-Pacific Journal of Operational Research, 30(06), 1350028. https://doi.org/10.1142/S0217595913500280

Wu, J., Liang, L., \& Song, M. (2010). Performance based clustering for benchmarking of container ports: An application of DEA and cluster analysis technique. International Journal of Computational Intelligence Systems, 3(6), 709-722. https://doi.org/10.1080/18756891.2010.9727734

Wu, J., Zhu, Q., Chu, J., An, Q., \& Liang, L. (2016). A DEA-based approach for allocation of emission reduction tasks. International Journal of Production Research, 54(18), 5618-5633. https://doi.org/10.1080/00207543.2016.1194537

Wu, W.-W. (2012). An integrated solution for benchmarking using DEA, gray entropy, and Borda count. The Service Industries Journal, 32(2), 321-335. https://doi.org/10.1080/02642069.2011.517833

Wu, W.-W., Lan, L. W., \& Lee, Y.-T. (2013). Benchmarking hotel industry in a multi-period context with DEA approaches: A case study. Benchmarking: An International Journal, 20(2), 152-168. https://doi.org/10.1108/14635771311307650

Yasin, M. M. (2002). The theory and practice of benchmarking: Then and now. Benchmarking: An International Journal, 9(3), 217-243. https://doi.org/10.1108/14635770210428992

Yazdani, M., Wen, Z., Liao, H., Banaitis, A., \& Turskis, Z. (2019). A grey combined compromise solution (CoCoSo-G) method for supplier selection in construction management. Journal of Civil Engineering and Management, 25(8), 858-874. https://doi.org/10.3846/jcem.2019.11309

Yeravdekar, S., \& Behl, A. (2017). Benchmarking model for management education in India: A total interpretive structural modeling approach. Benchmarking, 24(3), 666-693. https://doi.org/10.1108/BIJ-06-2016-0082

Yoshida, Y., \& Fujimoto, H. (2004). Japanese-airport benchmarking with the DEA and endogenousweight TFP methods: Testing the criticism of overinvestment in Japanese regional airports. Transportation Research Part E: Logistics and Transportation Review, 40(6), 533-546. https://doi.org/10.1016/j.tre.2004.08.003

Zhou, X., Luo, R., An, Q., Wang, S., \& Lev, B. (2019). Water resource environmental carrying capacitybased reward and penalty mechanism: A DEA benchmarking approach. Journal of Cleaner Production, 229, 1294-1306. https://doi.org/10.1016/j.jclepro.2019.05.004

Žižka, M., Hovorková Valentová, V., \& Turčok, L. (2016). Performance evaluation of Czech innovative companies: data envelopment analysis approach. International Journal of Strategic Property Management, 20(4), 427-438. https://doi.org/10.3846/1648715X.2016.1239592 